\title{
Halka Açık Anonim Şirketler Hukukunda Son Yıllardaki Önemli Gelişmeler
}

\author{
Significant Developments in Recent Years in the Law on Public Joint \\ Stock Companies
}

Hasan Pulaşlı ${ }^{*}$ iD

\section{öz}

Şirketler hukukuna ilişkin önemli değişme ve gelişmeler, ekonomik ve sosyal önemi nedeniyle en çok halka açık anonim şirketlerde gerçekleşmektedir. Özellikle bilimsel öğreti ve aynı şekilde kurumsal yönetim düzenleyici otoriteler, halka açık şirketlerin amacına bazı yeni idealler yükleyip, onu yeniden yorumlayarak ortaya yeni konseptler koydular. Bu bağlamda, "Üçlü-Kâr-İlkesi” konseptine (Triple-Bottom-Line), "paylaşılan değer yaratmak" (Creating Shared-Value), "sadakatli hissedarlar" (Loyalitätsaktionäre) ya da "sadakatli hisseler" (Loyalitätsaktie) ve anonim şirketlerin yönetim organlarında "kadın kotası" (Frauenquote) gibi konseptler sayılabilir. Bu makalede anılan konseptler incelenecektir.

Anahtar Kelimeler: Paylaşılan Değer, Üçlü Kâr İlkesi, Sadakatli Hisseler, Kadın Kotası

\section{ABSTRACT}

Significant changes and developments in company law occur primarily in the case of stock corporations due to their economic and social importance. In particular, the supervisory authorities for academic teaching and corporate governance have imposed some new ideals on the purpose of listed companies, reinterpreted them and presented new concepts. In this context, the "triple bottom line" concept of "creating common value", "loyalty shareholders" or "loyalty shareholders" (concepts such as loyalty share) and "quota for women" can be counted on the governing bodies of public companies. The concepts mentioned in this article are explored.

Keywords: Shared Value, Triple Bottom Line, Loyalty Shareholders, Women’s Quota

\section{GíRiş}

Bir ticaret şirketi olarak halka açı anonim şirketlerin temel amacının, uzun yıllar kârını maksimize ederek yatırımcılarını mutlu etme temeline dayanması, genel olarak gelirlerini azaltacak kurumsal sosyal sorumluluk bilinci ile hareket etmeleri ve doğal yaşamı doğrudan tehdit eden çevre ihlallerini önleyebilecek tedbirleri almalarına engel teşkil etmekteydi ${ }^{1}$. Bu durum, şirketin başta çalışanları ile faaliyette bulunduğu toplum ve diğer paydaşları arasında göz ardı edilemeyecek derecede büyük bir gerginliğe sebep olduğundan, bilimsel öğreti ve ondan beslenen kurumsal yönetimi düzenleyen otoriteler bunu ortadan kaldırmaya veya en azından azaltmaya yönelik yeni konseptler yaratmaya

* Prof. Dr., İstanbul Sabahattin Zaim Üniversitesi Hukuk Fakültesi Ticaret Hukuku Anabilim Dalı,

1 Bunun en güzel örneği, ünlü Alman otomobil üreticisi Volkswagen’in dizel araçlarında egzoz gazı salınımıyla ilgili manipülasyonu nedeniyle çevreye ve insan sağlığına verdiği zararlar karşılığında Amerika Birleşik Devletlerinde ve AB ülkelerinde ödediği onlarca milyar Dolar tazminatlar ve yöneticilerinin hapis cezaları almasıdır.

Sorumlu Yazar/Correspondence Author: Hasan Pulaşlı

E-posta/E-mail: hpulasli@hotmail.com

Geliş Tarihi/Received: $\quad 01.04 .2021$ 
çabaladılar. Bu bağlamda anonim şirketin ilk başta dip çizgisini teşkil eden tekil kârın optimizasyonu ilkesi "singuläre Bottum Line", "Üçlü-Kâr-İlkesi” konseptine (Triple-Bottom-Line) dönüștü. Bu, aşağıda I başlı̆̆ı altında incelenecektir.

Bu bağlamda ikinci değişim, halka açık anonim şirketlerde değer değişimine ilişkin gelişmedir. Yirminci yüzyılın sonlarında ortaya atılan ve öğretide de oybirliği ile kabul gören ve hemen kurumsal yönetim düzenlemelerinde yer almaya başlayan "Paysahipliği değerinin artırılması" (StakeholderValue-Ansatzes) ilkesidir. Ancak bu kavramın popülaritesi uzun sürmedi ve 2010 yılında yerini "paylaşılan değer yaratmak" (Creating Shared-Value) ${ }^{1}$ veya kısaca "paylaşılan değer" (Shared-Value) konseptine biraktı.

Üçüncü olarak, şirketin sürdürülebilir ekonomik gelişmesini ve aynı zamanda yönetim kurulunun girişimcilik program ve projelerini destekleyen "istikrarlı hissedarlar temelinde" "sadakatli hissedarlar" (Loyalitätsaktionäre) ya da "sadakatli hisseler" (Loyalitätsaktie) konseptinin uygulaması amacıyla yasal girişimler başlamış ve bazı ülkelerde de epeyi yol alınmıştır. Bu da, aşağıda II başlı̆̆ altında incelenecektir.

Dördüncü olarak, küresel alanda faaliyet gösteren çok uluslu şirketlerin yönetim organının, bağlı veya yavru şirketlerin insan hakları çevre standartlarının ihlalleri nedeniyle hukuki sorumluluğunun olup olmadığı sorunu ortaya atıldı ve mahkemelerden istenilen sonuç alınamayınca "Sivil Toplum Kuruluşlarının” (STK) inisiyatifiyle bununla ilgili bağlayıcı kuralların temel yasalarda yer alma çabaları başlatılmıştır. Bu da, aşağıda III başlığı altında incelenecektir.

Son olarak, özellikle halka açı şirketlerin yönetim organlarında kadın kotası uygulamasıyla ilgili yasal düzenlemelerdir. Birçok Avrupa ülkesinde şirketlerin yönetim organlarında kadın kotasına önceleri ihtiyatla yaklaşsa da, kamuoyundaki güçlü tepkiler nedeniyle önce yasal düzenlemelerde sonra da şirket sözleşmelerinde kadın kotasına yer vermeye başlamışlardır. Ancak, kadın hakları konusunda katı muhafazakâr tutumu ile tanınan İsviçre'de ${ }^{2}$, halka açı şirketlerin yönetim

1 "Paylaşılan değer yaratmak" (Creating Shared Value) kavramı, ilk kez Michael E. Porter ve Mark R. Kramer tarafından 2011'de Harvard Business Review'de, (January -February, 2011, 89 (1-2) 62-77), “Creating Shared Value” başlıklı makalede ortaya konuldu. Bu kavram öz olarak, şirketlerin faaliyet gösterdikleri bölgelerdeki sosyal ve çevresel koşulları iyileştirirken, aynı zamanda rekabet gücünü artırıcı politikalar ve uygulamalar olup, faaliyeti veya işleriyle kesişen sosyal sorunları belirleyip ele alarak ölçülebilir ekonomik fayda yaratan şirketler için odaklanmış bir iş stratejisi olarak tanımlanmaktadır. Ancak, bunun "paylaşılan değer" (Shared Value) olarak nitelendirilebilmesi için, şirkete tanımlanabilir bir ekonomik yararının yanı sıra sosyal veya çevresel bir konu üzerinde ölçülebilir bir etkisinin de olması gerekir. Paylaşılan değer, bir şirketin sosyal boyutunu, çalışanlarını, varlıklarını, ürünlerini, hizmetlerini, yatırımlarını ve sistemler arasındaki ilişkilerde şirket, tedarikçiler, tedarik zincirleri, müşteriler ve düzenleyiciler gibi dış paydaş gruplarıyla olan bağlarını dikkate alır. Sosyal veya toplumsal değere örnek olarak daha iyi sağlık, eğitim, erişimle ilgili alınan kararlara sivil toplum kuruluşlarının katılımı ve istihdam örnek olarak verilebilir. Bkz. Hasan Pulaşlı, Kurumsal Sosyal Sorumluluk Bağlamında Uluslararası İnsan Hakları ve Çevre Standartlarının Çok Uluslu Şirketlerin Merkez Yönetim Organının Hukuki Sorumluluğuna Etkisi, Batider 2020, C. XXXVI, S.4, s. 5-37.

2 İsviçre'li kadınların 1948 yılında başlayan federal düzeyde seçme ve seçilme hakkı, Almanya'dan 53, Avusturya’dan 52, Fransa'dan 27, İtalya'dan 26 ve Türkiye'den de 37 yıl sonra, 7 Şubat 1971'de sadece erkeklerin katıldığı referandumda 34.2 hayır oyuna karşı \%65.7 evet oyuyla gerçekleşti. Buna karşın, Kantonlarından Appenzell İnner-Rhodes'de ise, kadınların yerel seçimlere katılması 1991 yılında kabul edildi. İsviçre Federal Anayasasında "kadın erkek eşittir" ifadesi ise, 14 Haziran 1981'de yer aldı. Bkz. (https://ch2021.ch/geschichte/). Ancak, seçme ve seçilme hakkının elde edilişinin 50. yılında İsviçre parlamentosunda yüzde 41,5 kadın parlamenterin temsili, bir başarı örneğidir. Bu oran 
organlarında kadın kotası düzenlemesi, “Anonim Şirketler Büyük Revizyonu”na ilişkin 2020 tarihli Tasarıdan son aşamada çıkarılmış ve kanunlaşamamıştır. Buna karşın Fransa’da ise 1933 yılından beri büyük anonim şirketlerin yönetim kurullarında kadın kotası uygulanmaktadır. Bu konu, aşağıda $\mathrm{V}$ başlığ ${ }_{1}$ altında başta $\mathrm{AB}$ direktifleri olmak üzere mevcut birçok ülkedeki düzenlemeler çerçevesinde incelenecektir.

\section{HALKA AÇIK ANONIM ŞiRKETLERDE KÂR AMACINDAKI DEĞişME VE GELIŞMELER}

Anonim şirketin yasadaki genel tanımında, "iktisadi” (kâr elde etme) ve paysahipleri arasında paylaşma amacı bir asırdan beri temel unsur olarak yer alır. Bu kapsama, yatırım yaparak rizikoyu üstlenmiş yatırımcıların dişında üçüncü kişiler girmez. Her ne kadar İsviçre ve Almanya gibi ülkelerde anonim şirketin ideal (manevi) amaçlı olabileceği yasal zeminde kabul edilse de, pratikte pek revaçta değildir. Anonim şirket, türü itibariyle bir “yatırım” yapılacak kurumdur. Yatırımcıların temel amacı da, yatırımlarının ekonomik karşılığını almaktır. Halka açık olsun olmasın tüm anonim şirketlerin hedefi kâr elde etmek - hatta hayatta kalma meselesi olarak da - kâr elde etmek zorunda olması tartışmasızdır. Ancak, halka açık anonim şirketlerde tek kolona dayalı kârın maksimize edilmesine ilişkin bu katı ekonomik nitelik, 90'lı yılların sonunda "paysahipliği değerinin artırılması" (Shareholder-Value) temelinde değer değişimine (Wertwandel) uğradı. Bu amaçsal değişiklik sonucunda korunması gereken çıkar sahipleri kapsamına, sadece anonim şirkette paya (hisseye) sahip olan yatırımcılar (Anteilseigner) değil, aynı zamanda sosyal sorumluluk temelinde işletmenin faaliyetine katılan ve bundan etkilenen çalışanlar, tedarikçiler ve devlet gibi diğer menfaat sahipleri de (stakeholders) ${ }^{3}$ girmektedir.

İsviçre’yi dünyadaki 191 ülke içinde 17. sıraya yükseltmiştir. Ayrıca bkz. Nazire Akbulut, İsviçre’li Kadınların 170 Yıllık Mücadelesi (https://www.evrensel.net/haber/425382/isvicreli-kadinlarin-170-yillik-mucadelesi. Erişim. 27.3.2021). Önemle belirtilmesi gereken bir husus, Ülkemizde kadınların seçme ve seçilme hakkı, İsviçre'den çok önce, 1934'de kabul edilmesine rağmen, parlamentodaki kadın oranı dünyada 192 ülke arasında 117. sırada; Avrupa’da ise, 37 ülke içinde sondan üçüncü durumdadır (https://tr.euronews.com/2020/03/10/kadin-milletvekili-oraninda-turkiye-117-nci-siradazirvede-ruanda-ve-kuba-var. Erişim. 27.3.2021).

3 Bu konuda bkz. Peter, Forstmoser, Gewinnmaximierung oder soziale Verantwortung? Zum Auftrag börsennotierter Unternehmen, s. 207 vd (208) (https://www.forstmoser.ch/wp-content/publications/articles/2005-gewinnmaximierung. pdf. Erişim tarihi. 15.2.2021). Yazar, anonim şirketlerin hayatta kalma meselesi olarak kâr etmesi gerektiğinin tartışılmayacağını, ancak artık bunun daha çok sosyal açıdan sorumlu bir davranış, çalışanlar ve diğer paydaşlar açısından, aslında tüm ekonominin çıkarları için kârın maksimize edilmesi amacından vazgeçilerek taviz verilmesi gerektiği uygun değil midir? Soruları, ünlü Alman Bankası Deutsche Bank AG’nin yönetici kurul sözcüsü Jozef Ackermann’’n Der Spiegel Dergisi'nin Nr.2 28.2.2005 tarihli nüshasında yayımlanmış röportajındaki açıklamaya ve bunun sonucuna ilişkin olarak ortaya atmıștı. Ancak Yazar, bu sorulara yanıt verirken, öncelikle iki hususu saklı tuttuğu belirtmektedir. Birincisi, bu konuda son yarım yüzyılda bilimsel yayınlarla sınırlansa bile, halka açık şirketlerin kendilerini yönlendirmesi gereken hedefler hakkında sonsuz sayıda yazıların yazıldığın ve bu nedenle kendisinin bu tabloya ilişkin metin ve yorumlarda en iyi ve en önemli temsili bir seçimle belgelemeye çalışmadığını, ikinci olarak da, kendisinin İsviçreli olduğunu ve İsviçre hukuku açısından konuya ışık tutmaya çalıştığını, ancak anılan bankanın bu kararıyla ilgili olarak Alman hukuku alanında tavsiyelerde bulunmanın kendisinin işi olmadığını, ayrıca bunu yapmaya da yetkisinin olmadığına işaret etmektedir (s. 208, dn. 3). Son olarak yazar, bu bağlamda Almanya ile İsviçre arasında büyük şirketlerin faaliyetlerine ilişkin düşüncenin yanı sıra yasal zeminde de önemli farklılıkların olduğu ve İsviçre hukuku ve ekonomik politikalarının Alman sisteminden daha çok Anglo-Sakson ekolüne odaklandığını, bunun en önemli örneğinin, çalışanların yönetime katılmasının (Mitbestimmung) Alman şirketler hukukuna tam entegre olmasına karşın, İsviçre’de bunun 1976 yılında 


\section{A. Yönetim Kurulunun Şirketin Menfaatlerini Gözetme Yükümü}

Yasal düzenlemelerde, halka açık olsun olmasın tüm anonim şirketler için geçerli olmak üzere, yönetim kurulu üyeleri ve yönetimle görevli kişilerin... dürüstlük kurallarına uyarak şirketin menfaatlerini gözetmekle yükümlü olduğunu belirtilmektedir (İsvBK m. 717/1, "Der Verwaltungsrat einer schweizerischen Aktiengesellschaft ist verpflichtet, die Interessen der Gesellschaft in guten Treuen zu wahren"; AktG $\$ 93 / 1$ “Die Vorstandsmitglieder... auf der Grundlage angemessener Informationen zum Wohle der Gesellschaft zu handeln"; TTK m. 369/1 "Yönetim kurulu... şirketin menfaatlerini dürüstlük kurallarına uyarak gözetmekle yükümlüdür"4. Ancak, bu çıkarların nelerden oluştuğu kanunda belirtilmediği gibi, yasaya göre, yönetim kurulunun münhasıran hissedarların menfaatlerini korumasını ve hatta hissedarların menfaatlerini diğer menfaatlere nazaran önceliklendirmesini de gerektirmez. Bu durum, ABD'de şirketler hukuku ile ilgili mahkeme kararlarında tam tersi, yani "şirketin öncelikli olarak hissedarlara hizmet etmek zorunda olduğu" şeklindedir5

Şrketin menfaatine ilişkin diğer bir düzenleme de Sermaye Piyasası mevzuatında Kurumsal Yönetim İlkelerinde yer almaktadır. Paysahiplerinin kâr payı hakkına ilişkin ilkelerde (1.6.4) kâr dağıtım politikasında, hissedarların çıkarı ile şirket menfaati arasında dengeli bir politika izlenmesi belirtilmektedir. Bu ilkenin uygulanmaması halinde bu durumun gerekçesiyle birlikte Kurumsal Yönetim İlkelerine Uyum Raporu ile birlikte açıklanması gerekmektedir (Seri: IV, No:56 sayılı Tebliğ m. 5.1).

İsviçre öğretisinde, şirketin menfaatlerine ilişkin çeşitli tanımlar yapılmaktadır. Örneğin Schluep, kâr eden şirketin hissedarların, şirketin ve toplumun (ekonomi, alacaklılar, çalışanlar) çıkarlarına kalıcı olarak korunması anlamına gelen şirketin çıkarı kavramını geliştirdi ${ }^{6}$. Yazarın bu görüşü,

yapılan halk oylamasında reddedildiği (Schweiz. Bundesblatt 1976 II 662) belirtmektedir (s. 209 ve dn.5).

4 Alman hukukunda "Unternehmen an sich" olarak anılan teori, diğer menfaat gruplarına nazaran işletmenin çıkarına öncelik verilmesi, şirketi kuran paysahiplerinden ayrı bir hukuki kişiliğinin olduğuna dayanmakta ve şirketin varlığının devamına ilişkin bağımsız bir menfaati olduğu kabul edilmektedir, bkz. T. Ansay, Anonim Şirketler Hukuku 6. bası Ankara 1982, s. 22; F.H. Şehirali Çelik/ İ Kırca, Ç. Manavgat, Anonim Şirketler Hukuku, Ankara 2013, C.1, s. 271 ve dn. 882 vd 883 de anılan literatür.

5 Daniel Danaeker, Loyalitätsaktien - Postulat oder Rechtswirklichkeit? Sonder - druck aus Europa Institut Zürich Band 160 Mergers \& Acquisitions XVII Herausgeber: Rudolf Tschäni, Schultess Zürich 2015, s. 139-170 (https://silo.tips/ download/loyalittsaktien-postulat-oder-rechtswirklichkeit) (Erişim tarihi. 16.2.2021). "A business corporation is carried on primarily for the profit of the stockholders" (Dodge v. Ford Motor Company, Michigan Supreme Court, 170 NW 668 [1919](s. 143, dn. 12'den naklen).

6 Walter Schluep, Schutz des Aktionärs auf neuen Wegen? SAG 1960/61, 137 ff., 170 ff., 188 ff.; Forstmoser/Meier-Hayoz/ Nobel, Aktienrecht, Bern 1996, \$3, N. 17 ve $\$ 28$, N. 26. Peter Forstmoser, Profit - Das Mass aller Dinge? Zur Aufgabe börsenkotierter Unternehmen, in: Festgabe zum schweizerischen Juristentag, Zürich 2006, 55 ff., 71 f.; Forstmoser, Gewinnmaximierung oder soziale Verantwortung?' Zum Auftrag börsennotierter Unternehmen. In Summa: Dieter Simon zum 70. Geburtstag 2015, s. 207 ff., Yazar, büyük işletme işleten şirketlerin amacının kâr elde etmek olduğu -hatta bunun yaşam için zorunlu olduğu belirttikten sonra, hepsi bu mudur? Sorusunu yönelttikten sonra, sosyal sorumluluk bilincinde bir davranıştan ya da çalışanların çıkarına veya diğer menfaat sahiplerinin hatta tüm üst düzeyde ekonomik kâr maksimasyonundan vazgeçmek gerekir mi? Daha genel olarak, "bir şirket ekonomik öneme sahip olsa bile, hissedarlar için katma değer yaratmak bir anonim şirketin yönetim organlarının yegâne görevi midir? Sorularını ortaya artmaktadır. Yazar, yanıtları kendi içinde olan bu soruları aşağıda IV. Başlı̆̆ı altında ayrıntılı olarak incelenecektir. Öğretide, Watter/ Roth Pellanda, Basler Kommentar 4. Auflage, Basel 2012, Art. 717, N. 16, “...wobei im Rahmen der Zweckferfolgung dann insbesondere für eine nachhaltige Steigerung des Unternehmenswertes und damit des «Shareholder Value» zu sorgen ist" ("amacın takibi bağlamında, özellikle şirket değerinde sürdürülebilir bir "hissedar değeri" artışın sağlanması" olduğu belirtmekte, karşı görüsste Rudolf Bäre göre ("geradezu privatsrechtswidrig» und «dogmatisch verfehlte Zuflucht zu einem 
yeni literatürde, "stakeholder" ilkesi olarak tanımlandı. İsviçre Kurumsal Yönetim İlkelerinin (Swiss Code of Best Practice for Corporate Governance) 2014'teki yeni versiyonu Rz. 9'da, "yönetim kurulunun "şirketin kurumsal gelişiminden sorumlu" iken, hissedarların menfaatleri sadece tali olarak belirtilmiştir ${ }^{7}$. Son olarak Claude Lambert, 1992'de yazdığ doktora tezinde, şirketin çıkarları teriminin yargı kriterlerine göre değerlendirilemeyeceğinden, yönetim kurulunun eylemleri için objektif bir ölçüt olarak uygun olmadığını varsaymaktadır8.

\section{B. Halka Açık Şirketlerde Değer Değişimi (Wertwandel)}

Son yüzyılın 90'lı yıllarında bir saman alevi gibi ortaya çıan ve pratikte tartışmasız olarak kabul edilen "Paysahipliği değerinin artırılması" (Stakeholder-Value-Ansatzes) ${ }^{9}$ konseptinin ömrü uzun sürmedi ve 2000 'li yılların başlarında yerini, "paylaşılan değer yaratmak" (Creating Shared-Value) veya kısaca "paylaşılan değer" (Shared-Value) konseptine bıraktı1 ${ }^{10}$. Ancak, halka açı anonim şirketler için geçerli olan ilkesel nitelikteki kâr amacına yönelik değişiklik, yasal düzenlemelerde değil, bilimsel öğretide yumuşak yasa (Soft Law) olarak anılan ve tamamen "uygula ya da açıla" ilkesine dayalı tavsiye niteliğindeki 'Corporate Governance Richtlinie'de yer ald ${ }^{11}$. Hemen belirtelim, halka açı şirketlerin yönetim organlarının artık sadece şirketin menfaatine odaklanması görüşü artık aşılmıştır. Halka açık şirketler artık üç Efendi'ye hizmet etmek zorundadır: Bunlar:

a) Yatırımcıları yararına kârın maksimizasyonu,

b) Şirketin ve çalışanların çıkarlarını gözeten sosyal sorumluluk bilincine sahip bir davranış (Social Responsibility - sosyal sorumluluk),

Interessengegensatz Aktionär/Unternehmen») "Hissedar ile şirket arasında çıar çatışmasında özel hukuka aykırı ve dogmatik bir şekilde gözden kaçan sığınmadır. Ancak, Bär’in görüşünün öğretide pek taraftar bulmadığını belirtelim.

7 Bkz. Danaeker, Loyalitätsaktien, s. 144.

8 Claude Lambert, Das Gesellschaftsinteresse als Verhaltensmaxime des Verwaltungsrates der Aktiengesellschaft, Diss. Zürich 1992.

9 Paysahipliği değerinin artırılmasıyla ilgili olarak aktivistlerin gerçekte kurumsal hedefe tutarlı bir odaklanma olarak anladıkları şey, diğer menfaat sahipleri (Stakeholder-Value-Ansatzes) temsilcilerinin gözünde, bir şirkette meşru olan birçok gruptan yalnızca birinin çıkarlarına bencil ve sorumsuzca tek taraflı bir odaklanmadır. Bu doktrine göre, sorumlu davranış, hissedarların çıkarlarının yanı sıra aynı zamanda diğer menfaat sahipleri olarak anılan tüm paydaşların, yani çalışanların ve - büyük şirketlerde - kamunun çıkarlarının da dikkate alınmasını ve dengelenmesini gerektirmektedir. Bkz. Forstmoser, Gewinnmaximierung oder soziale Verantwortung? s. 210.

10 Bu yeni konsept, 1.10.2014'de yürürlüğe giren "Swiss Code of Best Practice of Corporate Governance"in önsözünde, Pràambel, ("Gesamtheit der auf das nachhaltige Unternehmensinteresse ausgerichteten Grundsätze»), (İșletmenin sürdürülebilir çıkarlarına yönelik ilkelerin bütünü” șeklinde tanımlandı.

11 Kurumsal yönetim ilkelerinin temel özelliği, uygulanmasının tamamen tavsiye niteliğinde olmakla birlikte, Türk hukukunda, ilk önce bu ilkeleri ortaya koyan Sermaye Piyasası Kurulunun oluşumu tamamen kamu otoritesine tabi olup, ayrıca kural koyma yetkisini haizdir ve bu düzenlemelerden 24 adedi de halka açık şirketler için uyulması zorunludur. Oysa İsviçre ve Alman kurumsal yönetim ilkelerini hazırlayan ve yayımlayan komitelerde siyasi otoritenin hiçbir temsilcisi yer almamış ve tamamen özel sektör temsilcileri ve akademisyenlerden oluşmuştur. Ayrıca, kodlardaki ilkelerin tümünde, "uy ya da açıkla" (Comply or explain) prensibi geçerlidir. Bkz., Pulaşl1, Hasan, Şirketler Hukuku Şerhi, 3. baskı Ankara 2018, 32, N.19-27. Pulaşlı, Compliance Kavramı ve Yönetim Organının Compliance Sorumluluğu, Batider, C.XXXV, Sa. 2, s. 27 vd (33-34). 
c) Çevreyi korumak için kaynak tasarrufu (verimliliği) sağlayan bir ekonomi (Environmental Responsibility-çevresel sorumluluk) ve insan haklarına sayg $1^{12}$.

Önemle belirtelim, 'paylaşılan değer' kavramı, şirketin yarattığı değer pastasının sadece katılan ve etkilenen gruplar arasında adil bir şekilde paylaşılması değil, aksine aynı zamanda tüm paydaşların çıkarları için daha fazla katma değer yaratma anlamını ifade etmektedir. Böylece, ünlü filozof Herakleitos'un, "değişmeyen tek şey değişimin kendisidir" felsefesine uygun olarak gelinen bu son noktada, halka açık anonim şirketlerin ilk başta en alt çizgisini oluşturan tekil kârın optimizasyonu ilkesi "singuläre Bottum Line", sofistik nitelikteki “Üçlü-Kâr-İlkesi” konseptine (Triple-Bottom-Line) ${ }^{13}$ dönüşmüş oldu.

Şirketlerin başarısı, sadece kârın maksimize edilmesi değil, aynı zamanda faaliyette bulunduğu topluma ne oranda katkı sağladığı, insan haklarına ve özellikle çevreye sağladı̆̆ı faydalarla birlikte ölçülmektedir. Böylece, işletmelerin, hem süregelen değişimleri takip etmeleri hem de rakiplerine karşı güçlü olabilmeleri, varlıklarını sürdürebilmeleri için öncelikle sosyal sorumlu, geleceği gören ve sorumluluklarının devamlılığını sağlayan bir vizyona sahip olmaları gerekmektedir ${ }^{14}$. Bu bağlamda, halka açı veya çok uluslu şirketlerde "kurumsal sosyal sorumluluk" (Corporate Social Responsibility) kavramı artık tek başına değil, aynı zamanda işletme performansının ekonomik, sosyal, çevre ve ekolojik parametrelerle de ölçülmesi anlayışına dayanan “üçlü-kâr-boyutu” olarak da adlandırılan "Triple-Bottom-Line, ${ }^{15}$ insan, evren ve kâr olmak üzere üç ilke üzerine oturulmaktadır. Bu konseptteki ekolojik boyut, çevrenin korunmasına yöneliktir, çünkü girişimci ve insan eylemleri doğa üzerinde olumsuz bir etkiye sahip olduğundan, çevre kirliliğine sebep olur. Ekolojik açıdan doğa, tutarlı bir ekosistem olarak kabul edilmekte ve çevreyi kirleten etkileri azaltacak önlemlere ek olarak, ekosistemin gelecek nesiller ve çevresel hedefler için de korunması gerekmektedir. Sosyal boyutu ise, işletmelerin faaliyette bulunduğu - yerel veya ülke düzeyinde olabilir - topluma sağlık, eğitim ve kültürel vb konularda gerekli katkılarda bulunarak, toplumla aradaki gerginliği azaltıp sosyal barışa katkı sağlayabilirler.

12 Forstmoser, Corporate Social Responsibility, s. 158. Ayrıca Hasan Pulaşl1, Kurumsal Sosyal Sorumluluk, Batider, Aralık 2020, C. XXXVI, S.4, s. 9 ve dn. 9,10 ve11'de anılan literatür.

13 Bkz. Neill Gatley, Introducing creating shared value, (https://www.british-assessment.co.uk/insights/spotlightintroducing-concept-creating-shared-value. Erişim tarihi: 31.11.2020). Aynı şekilde, Balı/Cinel, Nancy'nin (Kurumsal Sosyal Sorumluluk) Çevirisi: Sibel Kaçamak, 2. basım, İstanbul 2008, s. 2-3. Forstmoser, Corporate Social Responsibility, s. 158. "Triple-Bottom-Line" konsepti, Türk işletme biliminde "üç boyutlu muhasebe" veya "üçlü kâr modeli” olarak da tanımlanmaktadır. Bkz. Mihriban Coşkun Arslan, Harun Kısacık, The corporate Sustainability Solution: Triple Bottom Line, Muhasebe ve Finansman Dergisi Temmuz 2017 Özel Sayı, s. 18-34, Nuray Tokgöz - Saime Önce, Şirket Sürdürülebilirliği İçin Yeni Ölçümleme: Üçlü Performans, Afyon Kocatepe Üniversitesi, İ.̇̇.B.F. Dergisi, (2009), V. 1, s. $249-275$.

14 Başak Solmaz, İşletmelerin Değişen Konumuyla Gelişen Kurumsal Sosyal Sorumluluk Bilinci Ve Turkcell'in Desteklediği “Çağdaş Türkiye’nin Çağdaş Kızları” Projesinin Genel Bir Değerlendirmesi, Selçuk İletişim, DerPark, 2013-11-19, s. 116125. (s.117).

15 “Triple-Bottom-Line” kavramı Türk işletme biliminde “üç boyutlu muhasebe”, “üçlü kâr modeli” olarak da adlandırılmaktadır. Bkz. Coşkun Arslan, Mihriban Kısacık, Harun, The Corporate Sustainability Solution: Triple Bottom Line, Muhasebe ve Finansman Dergisi Temmuz 2017 Özel Sayı, s. 18-34, Tokgöz, Nuray/Önce, Saime (2009), "Şirket Sürdürülebilirliği İçin Yeni Ölçümleme: Üçlü Performans”, Afyon Kocatepe Üniversitesi, İ.İ.B.F. Dergisi, V. 1, pp. 249 275. 
Kıta Avrupası şirketler hukukuna yansıyan Amerikan hukukundaki bu gelişmelere bakıldığında, Triple-Bottom-Line konseptinden daha ne kadar ileriye gidilebileceği sorusu akla gelmektedir. Ancak bu bağlamda, İsviçre’nin ünlü ekonomi gazetesi "Neue Zürcher Zeitung - NZZ"nin ekonomi şef redaktörü Beat Gygìnin, anonim şirketlerin büyük revizyonuna ilişkin kaleme aldığ 2014 tarihli eleştirisel makalesinde, anonim şirketin "öffentliches Terrain" (kamu alanı) konumuna dönüşmemesi gerektiği uyarısı ${ }^{16}$ dikkate değer olmakla birlikte, Forstmoser' in haklı olarak belirttiği gibi, az ya da çok şans eseri ve özellikle güncel sosyal kaygılar ortaya çıktığında, aslında anonim şirketler hukukunda ekonomi ile ilgili güncel sosyo-politik konuları düzenlemek uygun ve cazip gözükebilir. Ancak, böyle bir durumda yapılacak yasal düzenlemenin, çarpık olmaktan öteye bir anlam ifade etmeyeceği olgusunu da göz ardı etmemek gerekir ${ }^{17}$. Bu durumda en uygun yöntem ve yol, yeni kurumsal yönetişim paradigması vasıtasıyla, topluma, çevreye ve uluslararası genel kabul gören insan haklarına saygılı "şirket kültürü"nün oluşturulmasıdır.

\section{HALKA AÇIK ŞIRKETLERDE YENI KATEGORI PAY TÜRÜ: SADAKATLi HISSELER (LOYALITÄTSAKTIE)}

\section{A. Sadakatli Hissedarlar Kavramının Ortaya Çıkış Sebebi}

2000'li yılın başlarında Avrupa'da sermaye piyasasında, halka açık şirketlerin yönetim kurulu üyeleri, bir hayalet gibi ortaya çıkan ve tamamen spekülatif yatırımcı amaçlı "aktivist hissedarlar" için sürdürülebilir değer yaratma çabalarını baltaladığını yüksek sesle dile getirerek şikayetçi olmaya başladılar. Buna karşı bir savunma önlemi olarak da, halka açık şirketlerde, yönetim kurulunun girişimcilik program ve projelerini destekleyen "istikrarlı hissedarlar temelinde" "çapa hissedarlar" (Ankeraktionäre) ${ }^{18}$ grubu oluşturulmasını önerdiler ${ }^{19}$.

Uzun vadeli hissedarların kısa vadeli spekülatörlere tercih edileceği varsayımının benimsenmesiyle, halka açık şirketlerde uzun vadeli hissedarlara ödenecek sadakat priminin” (Treueprämie) süresi ve miktarının ne kadar olması gerektiği sorunu ortaya çıktı. Öyle ya, sadakatli hissedarlar olarak anılan bu grubunun hissedarlarının elde edeceği prim, paylarını elde tuttukları süreye değmesi gerekirdi.

16 NZZ, 6.12.2014, s. 23 (Forstmoser, Corporate Social Responsibility, s. 173'den naklen) Keza Forstmoser, Corporate Social Responsibility, s. 173

NZZ, 6.12.2014, s. 23 (Forstmoser, Corporate Social Responsibility, s. 173'den naklen) Keza Forstmoser, Corporate Social Responsibility, s. 173

17 Forstmoser, Corporate Social Responsibility, s.173.

18 Bir şirkette önemli bir hisseye sahip hâkim veya çoğunluk hissedarları, "çapa hissedar” (Ankeraktionär) olarak adlandırılmakta ve bu paysahipleri sahip oldukları oy haklarıyla şirkette önemli kararları alabilecek gücü ellerinde bulundurmaktadırlar. Bunlar genellikle şirketin kurucu ailesinin üyeleri, kurumsal yatırımcılar şirketlerdir. Çapa hissedarları, uzun vadeli yatırım ufku ve şirketin geliştirilmesinde etkinliği ve amacıyla diğer hissedarlardan ayırt edilir. Ayrıntılı bilgi için, Watter Rolf, Anchor Shareholders und Grossaktionäre: Ihr Einstieg, ihre vertragliche Einbindung und ihre Information, in: M\&A XII, Zürich 2010, $1 \mathrm{ff}$.

19 Daniel Daeniker, Loyalitätsaktien - Postulat oder Rechtswirklichkeit?, Sonderdruck aus Europa Institut Zürich Band 160 Mergers \& Acquisitions XVII Herausgeber: Rudolf Tschäni, Schultess Zürich 2015, s. 139-170 (s. 140). 
Bilimsel öğretide bu tür sadakat primlerinin çeşitli türleri "sadakatli hisseler" (Loyalitätsaktien) olarak tanımlanmaktadır ${ }^{20}$.

Daeniker' in detaylı araştırmasındaki tespitlerde, İsviçre'de son yıllarda halka açık şirketlerin hisselerinin son on yılda istikrarlı bir şekilde giderek daha çok kısa vadeli ve ortalama elde tutulma süresinin de 12 ay olduğu belirlenmiştir ${ }^{21}$. Ancak, hisseleri kısa vadeli elde tutmanın da kısa vadeli düşünmeyi destekleyip desteklemediği başka bir sorundur. Burada öncelikle şirketler hukukunda hissedarlar ile şirket arasındaki ilişkinin değerlendirilmesi yapılacaktır.

\section{B. Payın Devredilebilirliği ilıesi}

Hisselerin geniş bir alana yayılmış olması, halka açık şirketlerin önemli yapısal nitelikleri arasında sayılmaktadır ${ }^{22}$. Pek çok girişimci proje, Pek çok girişimci proje ise, ancak çok sayıda piyasa katılımcısından büyük miktarda fon sağlanmasıyla gerçekleştirilebilir. Ancak hemen belirtelim, hissedarların dağınık ve aynı zamanda değişken olması ${ }^{23}$, bu projelerin gerçekleşmesine engel teşkil etmektedir, çünkü hissedarların bir tuşa basarak hisselerini bir anda satıp şirketten ayrilabilme mümkündür ve bunu yasaklayan bir hükmün esas sözleşmeye konulması da yasal olarak olanaklı değildir. Çünkü anonim şirketlerin evrensel ilkelerin biri de, paysahiplerine sermaye taahhüdünden başka bir borcun yüklenemeyeceğidir (TTK m. 480/1, İsvBK m. 680/1, AktG $₫ 54 / 1)^{24}$. Ayrıca, hamiline yazll paylarda devir serbestisi bir yana (TTK m. 489/1), nama yazilı payların da, kanunda ve esas sözleşmede aksi öngörülmedikçe, herhangi bir sınırlandırmaya bağlı olmaksızın devredilebileceği (TTK m. 490/1) veya şirketin onayıyla devredilebileceği (TTK m. 492/1), ancak esas sözleşme ile devredilebilirlik şartlarının da ağırlaştırılamayacağı öngörülmektedir (TTK m. 493/7). Dolayısıyla, hem hamiline hem de nama yazılı payların devrinin belirli süreli veya tamamen yasaklanması kanunen mümkün değildir. Diğer önemli bir husus, halka açık anonim şirketlerin hissedarlarının karakteristik özelliğinin, "genellikle ilgisiz, bazen yüzsüz ve aşırı durumlarda da sadakatsiz olduğu" belirtilmektedir ${ }^{25}$. Bu hukuki durum ve hissedarların niteliği karşısında, şirketin hissedarların paylarını en azından belirli bir süre elde tutmaya teşvik edecek bir takım geçerli hukuki enstrümanlara ihtiyaç olduğu açıktır. İşte şirketin orta veya uzun vadeli yatırımlarını gerçekleştirebilmesi için, payın serbestçe devredebileceği şartıyla, payları belirli süre elde tutan hissedarları ekonomik olarak ödüllendirmesi mümkün görülmektedir. İşte burada incelenecek olan "sadakatli hissedarlar" (Loyalitätsaktionäre) ya da "sadakatli hisseler" (Loyalitätsaktie) de tam olarak bu budur.

20 Daniel Daeniker, Loyalitätsaktien, s. 140.

21 Daniel Daeniker, Loyalitätsaktien, s. 141-142.

22 Bkz. Forstmoser/Meier-Hayoz/Nobel, \$2, N. 14.

23 Hasan Pulaşlı, Şirketler Hukuku Şerhi, 3. Baskı, \$28, N. 30.

24 Danaeker, bu durumu, Berle Adolf A./Means Gardiner C., The Modern Corporation and Private Property, New York 1932, 64 atfen bir deyimle şöyle ifade etmektedir [" It has often been said that the owner of a horse is responsible. If the horse lives he must feed it. If the horse dies he must bury it. No such responsibility attaches to a share of stock"] Mealen: (Bir atın sahibinin, at yaşıyorsa onu beslemesi gerektiği ve at ölürse onu gömmekle sorumlu olduğu sıklıkla söylenir). Ancak, hisse senedi ile ilgili böyle bir sorumluluk olmadığı belirtir, Bkz. Loyalitätsaktien, s. 143.

25 Danaeker, Loyalitätsaktien, s. 143, Biedermann Dominique/Daenıker Danıel, Pro \& Contra: Soll die Generalversammlung Managersaläre genehmigen? GesKR 2008, 142 ff., 15 ve dn.11'de anılan literatür. 
Öğretide, genel olarak halka açık şirketlerin hissedarlarının, "genellikle ilgisiz, bazen yüzsüz ve aşırı durumlarda da sadakatsiz olduğu" belirtilmektedir ${ }^{26}$. Bu durumda, bu nitelikteki hissedarları şirkette uzun süreli tutmanın bir yolu, diğer bir ifade ile hisselerini elde tutmaya teşvik edecek bir takım hukuki enstrümanlara ihtiyaç olduğu açıktır.

\section{Sadakatli Paylar (Loyalitätsaktie)}

\section{Kavram ve Tanım}

Kavramsal olarak hisse esas alındığında, "sadakatli hisseler" (Loyalitätsaktie), payın sahibi açısından da "sadakatli paysahipleri" (Loyalitätsaktionäre) olarak tanımlanmaktadır ${ }^{27}$. Öğretide, bu tür hisselerin özel kategori hisse değil, aksine "adi hisse" (Stammaktie) olduğu özellikle vurgulanmakta ${ }^{28}$ ve çeşitli ayrıcalıklar sunan ve birden çok kavramı barındıran "toplu bir kavram" (Sammelbegriff) olduğu vurgulanmaktadır ${ }^{29}$.

Sadakat hisseler, esas sözleşmeye dayalı olarak, sahibine belirli bir kesintisiz elde tutma süresinden itibaren paysahipliği haklarılya ilgili çeşitli ayrıcalıklar bahşeden adi hisselerdir (Stammaktie). Sadakatli hisselerin hedefi, kısa süreli hissedarlara nazaran daha iyi olan uzun vadeli elinde tutan hissedarları ödüllendirmektir ${ }^{30}$, çünkü hissedarların sadakati sonuçta şirkete de fayda sağlamaktadır ${ }^{31}$. Dolayısıyla, sadık hissedarlar olmadan anonim şirketin yönetimi, kârlılığın en güvenli kaynakları olan uzun veya orta vadeli hedeflerine ulaşmak için gerekli sürekliliğe sahip olamayacaktır ${ }^{32}$.

26 Danaeker, Loyalitätsaktien, s. 143, Biedermann Dominique/Daeniker Daniel, Pro \& Contra: GesKR 2008, 142 ff., 15 ve dn.11'de anılan literatür.

27 TDK Sözlüğüne göre "sadakat”, "içten bağlllık, sağlam güçlü dostluk" anlamlarını ifade etmektedir. Bu durumda, sadakatli hisseyi esas sözleşmede öngörülen süre (en az iki veya üç yll) elinde tutan hissedarların diğer hissedarlara nazaran belirli oranda kâr payı ve oy hakkında olduğu gibi daha fazla hak elde etmesi, içten bağlllık, sağlam dostluğa değil, tamamen maddiyata dayanmaktadır. Dolayısılla, sadece maddi amaç güden bu paysahiplerine "sadakatli" demek kanımca, sadakatin asıl anlamının aşınmasına, yozlaştırılmasına yol açar. Alman "Duden Rechtsschreibung" sözlügünde de, "loyalität" terimi, "Anstand" (erdem, terbiye), "Ehrlichkeit" (dürüstlük, temiz kalplilik, namusluluk), "Fairness" (Adalet, centilmenlik), "Zuverlässigkeit”" (güvenirlilik, inanılırlık) gibi "içtenlik, samimiyet, güvenirlilik gibi eş anlamlarını ifade etmekte, ama hiçbiri maddiyata dayanmamaktadır. Ancak bu kavramın yerine hangi terimin kullanılması gerektiği hususu ayrı bir sorundur. Bu durumda, tam anlamını yansıtmamakla birlikte, biz de burada uluslararası düzeyde kullanılan "sadakatli hissedar" terimini kullanacağız.

28 Bkz. Burckhardt, Loyalitätsaktien $s .369$.

29 Bkz. Hans Caspar von der Crone/Keivan Mohasseb, Stand der Aktienrechtsrevision Zehn Kernpunkte der ständerätlichen Debatte, AJP/PJA 8/2019, s. 781-794 (s. 792), («Sammelbegriff für verschiedene Privilegien»). Arthur Meier-Hayoz/Peter Forstmoser/Rolf Sethe, Schweizerisches Gesellschaftsrecht - Mit neuem Firmen und künftigem Handelsregisterrecht und unter Einbezug der Aktienrechtsreform, 12. A., Bern 2018, N. 148a (Hans Caspar von der Crone/Keivan Mohasseb'den, dn. 72'den naklen).

30 Hans Caspar von der Crone/Keivan Mohasseb, Stand der Aktienrechtsrevision, s. 792.

31 Daeniker, Loyalitätsaktien, s. 150.

32 Guyon Yves, La Loi du 12 Juillet 1994 sur le Dividende Majoré, Revue des Sociétés (1)1995, 2 ff („[...] sans actionnaires fidèles, la gestion naura pas la continuité nécessaire à la réalisation d’objectifs à long ou moyen terme, qui sont les sources les plus sûres de la rentabilité", aynı şekilde, Daeniker, Loyalitätsaktien, s. 150. 
Daniel Daeniker, sadakatli hisselere ilişkin ayrıntılı ampirik araştırmaya dayanan makalesinde, uzun vadeli hissedarların kısa vadeli spekülatörlere nazaran tercih edilebilir olduğu varsayımının doğru kabul edilmesi halinde, İsviçre halka açık şirketlerinin uzun vadeli hissedarlı̆̆ının bir sadakat bonusu şeklinde ne ölçüde ödüllendirilebileceği sorusunun ortaya çıktığı ve İsviçre öğretisinde bu tür sadakat ödüllerinin çeşitli şekillerinin "sadakat hisseleri" olarak tanımlandığını belirtikten sonra, sorunu ayrıntılı olarak dört başlık altında incelemektedir. Yazar ilk öncelikle, sorunun makroekonomik ve hukuki politik temellerini, özellikle halka açık şirketlerde farklı hissedar gruplarının çıarları arasındaki karşlıklı etkileşime dayanan gerilim alanı ele almakta ${ }^{33}$; daha sonra, sadakatli hisselerin uluslararası uygulamadaki mevcut durumunu ve ilk olarak Fransa'daki tarihi gelişimi ortaya koyduktan sonra üçüncü kısımda ise, İsviçre'deki mevcut şirketler hukukunun sadakatli hisselere ne derecede izin verdiğini incelemekte ve son olarak da, sadakatli hisselerin, geçerli olduğu kadarıla, arzu edilebildiği ve hedeflere uyumlu olduğunu tartışmaktadır ${ }^{34}$.

Payların ortalama elde tutma süresinin bir yıldan kısa olması dikkate alındığında, kesintisiz iki yıl elde tutma süresine sahip olan paysahiplerinin uzun vadeli olduğu kabul edilmektedir. Sürenin başlangıcı, pay defterine kayıt tarihinden itibaren işlemeye başlamaktadır. Süreye ilişkin sunulan kavramlar, genellikle bu varsayıma dayanmaktadır.

Ancak bilimsel öğretide, sadakatli payların uzun vadeli hissedar katılımını teşvik etme bağlamında uygulanabilir olup olmadığı tartışmalıdır ${ }^{35}$.

2014 yllından beri devam etmekte olan "Büyük Anonim Şirketler Hukuku Revizyonu” çerçevesindeki tartışmalarda gelinen son noktada, Parlamento çalışmalarıyla ilgili 2019 kış yasama döneminde Ulusal Mecliste (Nationalrat), hukuk komisyonunun tavsiyesi doğrultusunda sadakatli hisselerin, Tasarının 661a maddesinde yer almasına karar verildi ${ }^{36}$, ancak 2020 yll İlkbahar yasama döneminde Kantonlar Meclisi (Ständerat), baştan beri devam ettiği karşı görüşünde $1 s r a r$ etti ${ }^{37}$ ve sadakatli hisselere ilişkin düzenlemeler Tasarıdan çıkarıldı. Tasarıdaki düzenlemede, esas sözleşmede, en az iki yll pay defterine oy hakkına sahip olarak kaydedilmiş olan hisselerin sahiplerine, \%20'ye kadar daha fazla kâr payı verilebileceği öngörülebilmekteydi. Böyle bir hükmün esas sözleşmeye konulabilmesi için de, genel kurulda temsil edilen oyların en az üçte ikisinin ve oy hakkı bulunan esas sermayenin tamamının salt çoğunluğunun bir arada bulunduğu bir karar alınması gerekmekteydi ${ }^{38}$. Ancak, Tasarıdan çıkarılsa da, sadakatli hisseler sorununun, öyle veya böyle İsviçre siyasetini ve hukukunu meşgul etmeye devam edeceği söylenebilir.

33 Daeniker, Loyalitätsaktien, s.141 vd.

34 Daeniker, Loyalitätsaktien, s. 150 vd.

35 Christoph Burckhardt, Loyalitätsaktien im Rahmen der Aktienrechtsrevision, Das Aktienrecht im Wandel Zum 50. Geburtstag von Hans-Ueli Vogt, Dike Verlag AG, Zürich/St. Gallen 2020, s. 367-386. Ancak yazara göre, bu soru, şekli ve maddi bir bileșen, unsurdur (s. 370).

36 AB 2019 N 2385 ff. 2019 tarihli E-OR m. 661a/1 de, sadakatli hisselerin esaslarının esas sözleşmede yer alması, 2. fikrada ise ayrıntılarının iç yönergede düzenlenmesi öngörülmekteydi. Bkz. Burckhardt, Loyalitätsaktien im Rahmen der Aktienrechtsrevision, s.378.

37 Burckhardt, Loyalitätsaktien, s.378. AB 2020 S (prov.), Internet: https:// www.parlament.ch/de/ratsbetrieb/amtlichesbulletin/amtliches-bulletin-die-verhandlungen?SubjectId $=48501$

Art. 704 Abs. 1 Ziff. 8 bis E-OR 2019. 


\section{Türleri}

Sadakat hisselerinin norm konsepti objektif kriterlere göre yapılandırılmakta ve ayrıcalıkların bağlantılı olduğu üyelik hakkına bağlı olarak, uluslararası uygulamada sadakatli hisselere ilişkin genel kabul gören üç model ön plandadır.

(i) Sadakatli oy hakları (Loyalitätsstimmrechte). Uzun vadeli halka açı anonim şirket hissedarlarına oransallı ilkesine nazaran daha fazla oy hakkı vermektedir. Bu haklar, katılma haklarıyla bağlantılıdır.

(ii) Sadakatli temettüler (Loyalitätsdividenden). Uzun vadeli hissedarlara oransallık ilkesine nazaran daha yüksek tutarda temettü veya tasfiye artığından daha yüksek tutarda "sadakat prim" vermektedir. Bu haklar, mülkiyet haklarıyla bağlantılıdır.

(iii) Sadakatli rüçhan veya önerilmeye muhatap olma hakları (Loyalitätsbezugsrechte und vorwegzeichnungsrechte). Sermaye artırımı türleriyle ilgili olarak, taahhütlü, kayıtlı veya şartlı sermaye artırımı çerçevesinde, ilgili hissedara bir rüçhan hakkı veya ihraç bedeli çerçevesinde daha düşük bir ihraç fiyatı ödeme hakkı ya da önerilmeye muhatap olma hakkı veren haklardır. Bu haklar, koruyucu haklarla bağlantılıdır. Bu gruptaki imtiyazlar "diğer finansal araçlar" (andere Finanzinstrümente) şeklinde de anılmaktadır ${ }^{39}$.

(iv) Sadakat Opsiyonları (Loyalitätsoptionen). Paysahipliği haklarıyla bağlantılı olarak daha iyi bir konumun yanı sıra, diğer "diğer finansal araçlar" (andere Finanzinstrumente) şeklinde ayrıcalıklı bir hak düşünülebilir. Buna örnek olarak "sadakat opsiyonları" gösterilebilir, söz konusu haklara temel teşkil eden hisseleri belirli bir süre elinde tutan opsiyon hakkı paysahibine yeni ihraç edilen hisseleri belirli bir fiyattan satın alma hakkı tanımaktadır ${ }^{40}$.

\section{Sınırlandırılma}

Sadakat hisselerinin, "imtiyazlı paylar"dan (Vorzugsaktien) ayırt edilmesi gerekir ${ }^{41}$. Hemen belirtelim İsviçre hukukunda imtiyazlı paylar, adi paylara nazaran ayrı bir kategori oluşturmakta ve Türk hukukundaki gibi "imtiyaz" sayılmamaktadır ${ }^{42}$. Bu temel farklllığa rağmen, her iki hukuk sisteminde imtiyazlı (veya ayrı kategori) paylar, adi pay olan (Stammaktie) sadakat hisselerinin aksine, malvarlığı haklarıyla ilgili olarak adi paylara nazaran kâr veya tasfiye payından ya da yönetsel haklara ilişkin olarak oy hakkında ayrıcalık, üstünlük bahşetmektedir. Türk hukukunda, imtiyazlı payın sonradan esas sözleşme değişikliğiyle oluşturulması için genel kurul kararının sermayenin en az yüzde yetmişbeşini oluşturan paysahiplerinin veya temsilcilerinin olumlu oylarıyla alınması gerekir (TTK m. 421/3-b). İsviçre hukukunda ise, imtiyazın sonradan oluşturulması halinde,

39 Daeniker, Loyalitätsaktien s. 150, 160 vd. Yazar, dördüncü tür olarak, tamamen İsviçre modeli olarak belirttiği bağlı nama yazılı paylar çerçevesinde uzun süreli hissedarlığın değerlendirilmesi kapsamında - "sadakat bonusu" (Loyalitätsbonus) kavramına yer vermektedir (s. 165). Burckhardt, Loyalitätsaktien, s. 370.

40 Daeniker, Loyalitätsaktien - Postulat oder Rechtswirklichkeit?, s.163 vd

41 Karşılaştırın, TTK m. 478, 479; İsvBK m. 654, 656.

42 Bkz. Burckhardt, Loyalitätsaktien im Rahmen der Aktienrechtsrevision, s. 372 
paysahiplerine eşit işlem yapılması ilkesine uyulması ve mevcut paylara imtiyaz tanınması, hem tüm imtiyazh paysahiplerinin hem de genel kurulda temsil edilen tüm paysahiplerinin oylarıla alınan bir genel kurul kararıyla tüm mevcut payların sahiplerine tanınması gerekir ${ }^{43}$. İsviçre hukukunda oy ve malvarlığı haklarında ayrıcalıklı paylar, imtiyaz değil, ayrı bir pay kategorisi oluşturmaktadır.

Sadakat hisseleri, oy hakkında imtiyazlı paylardan da (Stimmrechtsaktien) ayırt edilmelidir. Oy hakkında imtiyazlı paylara, sermayeye katılma oranı ilişkisine göre daha fazla oy gücü bahşedilmektedir. $\mathrm{Bu}$, anonim şirketlerde hâkim olan ilkelerden, "sermaye oranında oy gücüne sahip olma" ilkesinden sapma teşkil eder. Esas sözleşme ile paya tanınan oy hakkında imtiyaz, payın herhangi bir elde tutma süresine bağlı olmaksızın sürekli olarak kullanır. Buna karşın sadakat hisseleri, esas sözleşmede öngörülen şekilde kesintisiz olarak belirli bir süre payın elde tutulması halinde söz konusu olur.

İmtiyazlı paylar, uzun vadeli hissedar katılımını teşvik etmek için uygun değildir. İlk başta, imtiyazların uzun vadeli hisselerle sınırlandırılmasının eşit işlem ilkesini ihlal edip etmediği de açık değildir. Böyle bir kısıtlama caiz olsa bile, imtiyazlı hakların, mülkiyetin elde tutma süresiyle ilişkilendirilmesi hukuken pek mümkün değildir ${ }^{44}$. Son olarak, devir durumunda bir hissenin malvarlığı veya oy hakkındaki imtiyaz hakkı alınmaz. İmtiyazlı payların kabul edilmesiyle, uzun vadeli hissedar katılımı, sürdürülebilir bir şekilde ileriye dönük olarak teşvik edilmek ve kolaylaştırılması yerine, geriye dönük olarak en fazla bir kez ödüllendirilebilir ${ }^{45}$.

\section{Sadakat Hisselerine Ilişkin Eleştiriler}

İsviçre Parlamentosundaki tartışmalarda, sadakat hisseleri kavramının henüz olgunlaşmadığı ve etkileri konusunda da belirsizlikler olduğu ileri sürüldü. Bu endişeler, daha çok Fransadaki sadakat kâr paylarının etkisine ilişkindi. Öğretideki görüşe göre, söz konusu konsept Fransa’daki şirketler uygulamasında kendisini kanıtlamıştır ${ }^{46}$. Bu görüş, Air Liquide SẢnın hissedar tabanına ilişkin analizle de teyit edilmiştir. Sadakat temettüsü ödemeyi uygulayan şirketlerden biri olan CAC-40

43 Bkz. İsvBK m. 684/2 "Hat eine Gesellschaft Vorzugsaktien ausgegeben, so können weitere Vorzugsaktien, denen Vorrechte gegenüber den bereits bestehenden Vorzugsaktien eingeräumt werden sollen, nur mit Zustimmung sowohl einer besonderen Versammlung der beeinträchtigten Vorzugsaktionäre als auch einer Generalversammlung sämtlicher Aktionäre ausgegeben werden". Burckhardt, Loyalitätsaktien s. 372.

44 Sonuçta Peter Forstmoser, Corporate Social Responsibility, eine (neue) Rechtspflicht für Publikumsgesellschaften?, in: Robert Waldburger et al. (Hrsg.), Law \& Economics, Festschrift für Peter Nobel zum 70. Geburtstag, Bern 2015, 157 ff., (s. 179, [ "Ein Einsatz dieser Instrumente zur Förderung der Nachhaltigkeit dürfte aber daran scheitern, dass es - was hier nicht näher ausgeführt werden kann - aktienrechtlich höchst problematisch wäre und technisch kaum umsetzbar sein dürfte, solche Privilegien an die Haltedauer der Aktien zu knüpfen"] (Bununla birlikte, sürdürülebilirliği teşvik etmek için bu araçların kullanılması büyük olasılıkla başarısız olacaktır, çünkü - burada daha ayrıntılı olarak açıklanması gerekmez - anonim şirketler hukuku kapsamında son derece sorunlu olur ve bu tür ayrıcalıkların hisselerin elde tutulma süresine tanınması teknik olarak pek mümkün değildir). Aynı şekilde, Burckhardt, Loyalitätsaktien, s. 372 .

45 Burckhardt, Loyalitätsaktien s. 372.

46 Michael Storck/Uwe H. Schneider, Doppeltes Stimmrecht für langfristig investierte Aktionäre im französischen Recht - Ein Beitrag zur «Nachhaltigkeitsprämie», AG 2008, 700 ff., 706 (Christoph Burckhardt, Loyalitätsaktien, s. 382'den naklen). 
Şirketinin amacı dengeli ve istikrarlı bir hissedar tabanı oluşturmaktı. Nitekim Air Liquide SA sağlam bir bireysel hissedar tabanı oluşturduğu gibi, hissedarlarıyla da doğrudan iletişimi geliştirdi. Sonuç olarak, 2004-2014 döneminde bireysel hissedarların oranı, sermayenin yüzde 35 ilâ 40’’arasında sabit kalırken, diğer CAC- 40 şirketlerinde ortalama olarak azald 1 ve mali krizden bu yana $\% 8$ 'in altına düştü. 31 Aralık 2015 itibariyle, sermayenin toplam değeri yüzde 30 olan hisseler, sadakat temettü ödemesi için gerekli şartları karşıladı. 31 Aralık 2018 itibariyle, hissedarların \%64'ünden fazlası hisselerini 10 yıldan fazla bir süredir elinde tutuyordu ${ }^{47}$. Böylece, Air Liquide şirketi, sadakat temettüsü uygulayarak, CAC-40 şirketlerinin ortalamasından daha istikrarlı bir hissedar tabanı oluşturdu ve uzun vadeli odaklı iş stratejisi güden bir şirketin temeli atmış oldu. Şirket ayrıca, pay defterine kayıtlı hissedarların oranını sürekli olarak artırmayı veya korumayı da başardı. Görünen o ki, şirket, 2014’te Belinfanti tarafından tanımlanan yeni bir "hissedar yetiştirme konseptini” (Konzept der shareholder cultivation) uygulamaya koymuş olmaktadır ${ }^{48}$.

Hisselerin elde tutma süresini haklı göstermek için eşit işlem ilkesine dayanan bir gerekçenin sunulmasının yanlış bir kriter olduğu ileri sürülerek eleştirildi. Ayrıca, hisselerin devredilmemesiyle ilgili sadakat süresinin iki yıldan fazla olması gerektiği vurguland1 ${ }^{49}$. Ancak, Burckhardt'ın yerinde olarak belirttiği gibi, eğer Tasarıdaki teklif anlamında sadakat hisseleri açıkça bir yasal temele dayanıyorsa, hissedarlar arasında eşit olmayan işlemden bahsedilmesi mümkün değildir ${ }^{50}$. Ancak öğretide, İsvBK'daki mevcut düzenlemeler karşısında, kuruluşta veya daha sonra esas sözleşme değişikliğiyle, hisseleri uzun süre elde tutan hissedarlar için baştan imtiyazlar öngörülmesinin geçersiz olup olmadığı tartışmalıdır ${ }^{51}$. Tartışmaların ayrıntısına girmeden, eğer İsvBK'daki temettü imtiyazına ilişkin mevcut düzenlemeler sadakatli hisseler için de yeterli olsaydı, dört yıldan beri sadakat hisselerine ilişkin yasaya yeni hükümlerin konulmasının tartışılmasına gerek kalmazdı. Sonuçta, yasa koyucunun sadakatli hisselere diğer adi hisselere nazaran \%10 veya daha fazla temettü verilmesini yeterli ve geçerli bulmadığı için mevcut yasaya özel hüküm konulmasını istemediği söylenebilir. Bununla birlikte, sadakatli temettülerin amacının, uzun vadeli bir hissedar tabanı oluşturmayı teşvik ettiği kuşkusuzdur. Ampirik araştırmadan elde edilen kanıtlara göre, katılma durumunun devamlılığı, dengelenmiş bir hissedar tabanı oluşturulmasının öncelikle şirketin menfaatine yöneliktir ${ }^{52}$.

47 Burckhardt, Loyalitätsakktien, s. 382.

48 Tamara C. Belinfanti, Shareholder Cultivation And New Governance, Delaware Journal Of Corporate Law [Vol. 38), 2014, s. 790 ff, (807). ["Shareholder Cultivation primarily involves the interplay between a firm and its shareholders. Nonetheless, viewing Shareholder Cultivation through a new governance frame has analytical currency"] (Hissedar yetiştirme, öncelikle bir şirket ile hissedarları arasındaki etkileşimi içerir. Bununla birlikte, yeni bir yönetişim çerçevesi aracılığıyla hissedar yetiştirme kültürünün değerlendirilmesi analitik güncellemeyle de yapılır). Aynı şekilde, Burckhardt, Loyalitätsakktien, s. 382-383.

49 Oberholzer temsilcisi Leutenegger' in görüşü, AB 2018 N.1102 (Bkz. Burckhardt, Loyalitätsakktien, s. 383).

50 Burckhardt, Loyalitätsakktien, s. 384

51 Olumlu görüş, Forstmoser, Corporate Social Responsibility, s. 180, Burckhardt, Loyalitätsakktien, s. 384. Karşı̈ görüş, Peter Böckli, Aktienrecht, 3. Auflage, Zürich, Basel Genf 2004, $\$ 13$, N. 510, Wolfhart F. Bürgi, in: Kommentar zum Schweizerischen Zivilgesetzbuch, Das Obligationenrecht, 5. Teil: Die Aktiengesellschaft, b/1, Rechte und Pflichten der Aktionäre (Art. 660-697), Zürich 1957, Art. 660/661 N 30, Theo Guhl, Das schweizerische Obligationenrecht, 9. Auflage, Zürich 2000, 67 N 38 .

52 Bkz. Burckhardt, Loyalitätsakktien, s. 384. 


\section{Sadakat Hisselerinin Aile Tipi Anonim Şirketlerdeki Sakıncalara Ilişkin Eleştiriler}

Anonim Şirketler Büyük Revizyonuna İlişkin 2018 tarihli Tasarının danışma, tartışma (Vernehmlassung) sürecinde, İsviçre Halka Açık Olmayan Anonim Şirketler Birliği (Vereinigung der Privaten Aktiengesellschaften), 12.06.2020 tarihli bildirisindeki sadakat hisselerine ilişkin olumsuz görüşünde miras hukukundan örnek vererek şöyle bir açıklamada bulunmuştur. İlk bakışta sempatik gözüken sadakatli hisselerin, aile tipi anonim şirketler için zehirdir çünkü "sadakat ayrıcalığı"na ilişkin esas sözleşme değişikliği en az üçte iki pay veya sermaye çoğunluğuyla gerçekleştirilebilecektir. Bunun anlamı, çoğunluk paysahipleri uygun esas sözleşme değişikliğini azınlığın iradesine karşı yapabilecek ve kendileri için uygun ayrıcalıkları elde edebilecek demektir. Bu durum, özellikle bir aile anonim şirketinde bir paysahibinin ölmesi ve mirasçılarının (birlikte en az üçte iki pay veya sermayenin çoğunluğuna sahip olmayan) yeni hissedar olabilmesi mümkündür. Onları ailesi veya aile soyundan olanlar, diğer hissedarlar gibi payları ayn süre boyunca elinde tutsalar bile, dezavantajlı duruma düşebilirler. Ya da bir aile hissedarının daha önce hisse sahibi olan daha büyük çocukları, daha sonra hisse alan küçük kardeşlerine kıyasla neden "sadakat ayrıcalıklarından” yararlanabilsin? Bu tür eşitsiz durumun, aile şirketlerinde kaçınılmaz olarak tartışmalara yol açacağı açıktır ${ }^{53}$.

\section{Uluslararası Uygulamada Sadakatli Paylar}

\section{a. Avrupa Birliği Hukukunda}

İki binli yılların başında Avrupa Şirketler Hukukunda orantılılık ilkesi ve katılma hakkı ile oy gücü hakkı (One share, one vote) arasında senkronizasyon tartışılmaktaydı. 2002 yılında tüm Avrupa Birliği genelinde borsaya kote şirketlerde oy hakkında imtiyaz, altın pay ve diğer kontrol mekanizmalarını tamamen ortadan kaldırmak için girişimlerde bulunuldu. Bu tür kontrol araçlarının efektif etkilerine ilişkin 2007'de yayınlanan bir araştırmada, çok farklı bir sonuca ulaşıldı. Sorun göründüğü kadar da dramatik değildi. Bu nedenle, 2007 yılının sonunda Avrupa Komisyonu, oy ve sermaye gücünün standartlaştırılmasına ilişkin düzenleyici projesini rafa kaldırdı ${ }^{54}$.

Avrupa Komisyonu 2012'de, Avrupa Şirketler Hukuku ve Corporate Governance hakkında bir aksiyon planı hazırladı ${ }^{55}$. Bu eylem planının bir parçası olarak, hissedarların kurumsal yönetim ilkeleri çerçevesinde daha fazla yer almaya teşvik edilmesi gerektiği belirtildi ${ }^{56}$. Bu, uzun vadeli hissedar katılımını teşvik eden ve kolaylaştıran girişimleri içermekteydi ${ }^{57}$. Komisyon 25 Mart 2013’te “Avrupa Ekonomisinin Uzun Vadeli Finansması”na ilişkin Yeşil Kitap (Grünbuch) yayımladı. Ancak

53 Die Loyalitätsaktie ist für Familienaktiengesellschaften Gift, 12.06.2020 Mitteilung, (https:/www.vpag.ch/images/pdf/ medienmitteilungen/12_06_2020_Medienmitteilung_Loyalitaetsaktie.pdf. Erişim. 6.3.2021).

54 Daeniker, Loyalitätsaktien, s. 159.

55 Bkz. Mitteilung der Kommission an das europäische Parlament, den Rat, den europäischen Wirtschafts - und Sozialausschuss und den Ausschuss der Regionen, COM (2012), 740/2.

56 Aktionsplan, s. 4.

57 Daeniker, Loyalitätsaktien, s. 159. 
kitapta, uzun vadeli yatırımcı hissedarlığını teşvik etmeyi amaçlayan daha fazla oy hakkı ve temettü gibi haklar yer almamaktayd ${ }^{58}$.

Komisyonun 27 Mart 2014 tarihli son raporunda 59 , "sadakatli hisseler" den artık bahsedilmemesi, bu aracın $\mathrm{AB}$ alanında Corporate Governance ilkelerini iyileştirmek için yeterince etkili olmadığının kabul edildiği anlamı geldiği söylenebilir ${ }^{60}$.

AB’nin 2007/36/EG sayılı Direktifinin değişikliğine ilişkin 2017/828 sayılı Direktifinde (zur Änderung der RL 2017 /828 im Hinblick auf die Förderung der langfristigen Mitwirkung der Aktionäre (ARUG II), hissedarların borsaya kote şirketleri etkileme ve şirketler hakkındaki bilgi düzeylerini geliştirme becerilerini güçlendirme amaç edinilmiş olup, sadakatli hissedarlardan söz edilmemektedir.

\section{b. Fransız Hukukunda}

1933 tarihli bir yasada, esas sözleşmede öngörülmesi kaydıyla, Fransız hissedarlarla sınırlı olarak, "fidélité personnelle" (kişisel sadakatli) hissedarlara belirli koşullar altında çifte oy hakkı verilmişti. Bu düzenleme, AB (Avrupa Birliği) içinde vatandaşlık temelinde ayrımcılık olasılığı nedeniyle 1966 yılında Code de Commerce’in revizyonunda kaldırılmasına rağmen, esas sözleşmelerde bu hak hâlâ "AB - Hissedarları (EU-Aktionäre" şeklinde yer almaktadır ${ }^{61}$.

Fransız Şirketler Hukukunda, sadakatli oy hakları, aşağıdaki koşullar altında paysahiplerine tanınabilir:

1996 tarihli Code Commerce’e göre, sadakatli oy haklarının geçerli olabilmesi için, ilgili şirketin esas sözleşmesinde bir düzenleme olması gerekir. Ancak, borsaya kote şirketler için Nisan 2014’ten beri Florange Yasası (Loi Frolange) ${ }^{62}$ nedeniyle, sadakatli oy hakları yasal olarak mevcuttur. İlgili hüküm şöyledir:

[“„Dans les sociétés dont les actions sont admises aux négociations sur un marché réglementé, les droits de vote double prévus au premier alinéa sont de droit, sauf clause contraire des statuts adoptée postérieurement à la promulgation de la loi nº 2014-384 du 29 mars 2014 visant à reconquérir l'économie réelle [...].“

"Hisse senetleri düzenli bir piyasada işlem gören şirketlerde, ilk fikrada öngörülen çifte oy hakkı, reel ekonomiyi eski haline getirmeyi hedefleyen 29 Mart 2014 tarih ve 2014-384 sayll Kanunun yürürlüğe girmesinden sonra kabul edilen esas sözleşmede yer alan hüküm hariç olmak üzere geçerlidir”.

58 Bkz. Grünbuch, 18 ve Daeniker, Loyalitätsaktien, s. 159.

59 Mitteilung der Kommission an das europäische Parlament und den Rat über die langfristige Finanzierung der europäischen Wirtschaft, COM (2014), s. 168

60 Daeniker, Loyalitätsaktien, s. 160

61 Art. L 225-123 Abs. 3 Code de Commerce, Daeniker, Loyalitätsaktien, s.151, dn. 45.

62 Loi nº 2014-384 du 29 mars 2014 visant à reconquérir l'économie reelle (29 Mart 2014 tarih ve 2014-384 say1lı Kanun, reel ekonominin geri kazanılmasını hedefliyordu). Daeniker, Loyalitätsaktien, s.151. 
$\mathrm{Bu}$ düzenlemeye göre, çifte oy hakkı, esas sözleşmede öngörülmesi gerekmeksizin, borsaya kote şirketlerde otomatik olarak uygulanır. Bununla birlikte şirket, esas sözleşmede çift oy hakkına ilişkin imtiyazın hariç tutulduğunu belirleyebilir.

- Daha fazla oy hakkını içeren hisseler, pay defterine kaydedilmiş olmalıdır.

- Çift oy hakkının verildiği hisseler en az iki yıl süreyle elde tutulmuş olmalıdır.

Bu koşulları sağlayan uzun vadeli hissedarlar, çift oy hakkını elde etmiş olur. İç kaynaklardan sermaye artırımında bedelsiz pay çıkarılması halinde, kök paylara ilişkin çift oy hakkı, yeni oluşturulan paylarda da geçerli olur ${ }^{63}$.

Paysahibi fazla oy hakkını, pay defterinde artık kayıtlı olmaması veya payını devretmesi halinde kaybeder ${ }^{64}$.

Sadakatli temettü hakkının koşulları ve azami yüzde oranı şöyledir:

- Sadakatli oy haklarında olduğu gibi, sadakatli temettü hakkı için de öncelikle esas sözleşmede bir hükmün yer alması gerekir.

- Sadakatli hisseler, sadece pay defterine kaydedilmiş nama yazılı paylar için öngörülebilir.

- Hisseleri elde tutma süresi, hesap yılının kapanış tarihi esas alınmak üzere, iki yıldır. Temettü dağıtım zamanında, hissedarların pay defterinde kayıtlı olması gerekir ${ }^{65}$.

- Süper temettü, normal temettülere nazaran en fazla \%10 tutarında olabilir.

- Borsaya kote şirketlerde sadakat temettüsü, -küçük hissedarla öncelikli olmak üzere - her bir hissedara esas sermayenin maksimum $0.5 \%$ oranında olabilir.

Süper temettü hakkı, paysahibinin pay defterinde kayıtlı olmaması veya payını devretmiş olması halinde kaybedilir ${ }^{66}$.

Daniel Daeniker, "sadakatli opsiyon hakları"nın Fransız Code Commerce'de yer almamakla birlikte, öğretide örnek olarak Michelin şirketinin 1991 yllında yeniden yapılanma çerçevesinde ihraç ettiği hisselerle ilgili kâr payı kesintisini içeren durumun gösterildiğini belirtmektedir. Buna göre, temettü kesintisine uğramak zorunda kalan hissedarlara o tarihte 1:10 oranında dört yll süreyle kullanılabilecek opsiyon hakkı tanındı. Hak sahipleri, o zamanki 115 Fransız Frankı (FRF) olan bir hisseyi dört yıl sonra 200 FRF satın alma fiyatı üzerinden kullanabilecekti. Buna ek olarak yönetim kurulu, hisselerini 1993 yilı sonuna kadar elinde tutan hissedarlara, elde tutulan her 10 hisse için bir hisse elde edeceklerine ilişkin ikinci bir seçenek hakkı vermişti. Bu sadakat opsiyonundan ancak, hisselerini yapılanma süreci boyunca elinde tutan hissedarlar yararlanacaklard ${ }^{67}$. Michelin' in daha sonraki hisse kur fiyatının gelişmesi göz önüne alındığında, bu proje hissedarlar için iyi bir ticaret

63 Art. L225-123 Abs. 2 Code de Commerce. Daniel Daeniker, Loyalitätsaktien, s. 152.

64 Art. L225-124 Abs. 1 Code de Commerce. Daeniker, Loyalitätsaktien, s.152.

65 Daeniker, Loyalitätsaktien, s.153.

66 Daeniker, Loyalitätsaktien, s.154.

67 Daniel Daeniker, Loyalitätsaktien, s.154-155. 
olmuştu, zira 200 FRF olan kullanma fiyatı, kullanma periyodu sürecinin yarısında 200 FRF fiyatının üzerindeydi ve en uzun boğa piyasası olarak anılan hisselerin yükseliş kuru, sadakat periyodu sona erdiğinde neredeyse aynı zamanda gerçekleşmiş olmaktayd ${ }^{68}$.

\section{c. Hollanda Hukukunda}

Hollanda Şirketler Hukukunda sadakat hisseleri yasal olarak düzenlenmemiştir, ancak münferit uygulamalarla geliştirilmiştir. Bunun en iyi örneği de, kimya konzerni olan Koninklijke DSM N.V. tarafından oluşturulan sadakat hisseleridir ${ }^{69}$. DSM Konzerni, 2007 yılında yaptığı esas sözleşme değişikliğinde, pay defterine kayıtlı olan hissedarların üç yıl sonra, geçen üç yılda aldıkları ortalama kâr payının \%30’u oranında süper temettü alacakları öngörüldü. Buna göre, her yıl \%10 oranında bir süper temettü ödemesi yapilacaktır. Ancak, bu düzenlemeye, Franklin Templeton yatırım fonlarının yatırım danışmanı, Franklin Mutual Advisers, kâr payında imtiyazın yalnızca ayrı bir pay kategorisi oluşturma çerçevesinde caiz olacağını ve ek olarak esas sözleşmenin bu yeni hükmünün de, hissedarlara objektif bir gerekçeye dayanmayan eşit işlem ilkesi uygulamasına yol açtığını ileri sürerek mahkemeye başvurdu ${ }^{70}$. Davacıların itirazına ilişkin ilk gerekçe, "esas sözleşmede aksi öngörülmemişse, tüm hissedarların haklarının itibari değere göre belirleneceği”ne ilişkin Hollanda Medeni Kanunu (Burgerlijk Wetboek= BW) m. 2: 92 (1) hükmüne ${ }^{71}$ dayanmaktaydı. İkinci gerekçe olarak, BW m. 2: 92 (2) hükmündeki, halka açık bir şirketin, aynı konumda olan tüm hissedarlara eşit işlem yapması hükmüne dayanmaktayd ${ }^{72}$.

Dava ve talep, ilk derece mahkemesi (Amsterdam Appellationsgericht) tarafindan kabul edildi. Mahkeme, BW m. 2: 92(1) hükmü uyarınca, hissedarların eşit olmayan malvarlığı haklarıyla ilgili durumda, ayrı bir pay kategorisi oluşturulmasının zorunlu olduğuna karar vermiştir. İtiraz üzerine ülkenin en yüksek Mahkemesi olan Hollanda Yüksek Konseyi (Der Hohe Rat der Niederland), ilk derece mahkemesinin söz konusu kanun maddesini çok dar yorumladığını ve BW m. 2:92 (1) hükmünde, yeni bir özel kategori pay oluşturulması değil, sadece esas sözleşmelerde münferit hissedarlar için olası bir imtiyazın yer almasının gerekli olduğunu belirtti ve DSM Konzernin de tam olarak bunu yapmıştır, şeklinde değerlendirmede bulunmuştur. Bu nedenle, imtiyazlı pay oluşturmaksızın, sadakat temettüsü verilmesine ilişkin esas sözleşme hükmü geçerlidir ${ }^{73}$. Yüksek Mahkeme, usul hukukuna ilişkin nedenlerden dolayı, davacıların ileri sürdüğü, hissedarlara eşitlik ilkesine aykırı işlem yapıldığı iddiasını ele almamışıır ${ }^{74}$.

68 Daniel Daeniker, Loyalitätsaktien, s.154.

69 Daniel Daeniker, Loyalitätsaktien, s. 156 vd.

70 Bkz. Daeniker, Loyalitätsaktien, s.156 vd. ve dn. 55'de anılan literatür.

71 ("Voor zover bij de statuten niet anders is bepaald, zijn aan alle aandelen in verhouding tot hun bedrag gelijke rechten en verplichtingen verbonden"). "Esas sözleşmede aksi belirtilmemișse, tüm hissedarlar itibari değere göre aynı hak ve yükümlülüklerle tabidir). Daeniker, Loyalitätsaktien, s. 156, dn. 56’tan naklen.

72 ("De naamloze vennootschap moet de aandeelhouders onderscheidenlijk certificaathouders die zich in gelijke omstandigheden bevinden, op dezelfde wijze behandelen") "Halka açık şirketlerin, aynı konumda bulunan pay veya ilmühaber sahiplerine aynı şekilde işlem yapması gerekir”. Daniel Daeniker, Loyalitätsaktien, s. 157, dn. 57'den naklen).

73 Daeniker, Loyalitätsaktien, s.157.

74 Daeniker, Loyalitätsaktien, s.157 
Ancak, DSM Konzerni kendi isteğiyle sadakat hissesi programını uygulamaktan vazgeçtiğine ilişkin karar verdiğinden, mesele nihai olarak kapanmış olmamakla birlikte, sadakat hisselerini uygulamasına ilişkin hukuki yolun açıldığı söylenebilir.

\section{d. Isviçre Hukukunda}

"Büyük Anonim Şirketler Hukuku Revizyonu” çerçevesinde İsviçre Ulusal Meclisi (Nationalrat) ile Kantonlar Meclisi (Ständerat) arasında 2014 yılından beri devam eden görüş ayrılığında gelinen son noktada, Meclis çalışmalarıyla ilgili 2019 kış yasama döneminde Ulusal Meclis, hukuk komisyonunun tavsiyesi doğrultusunda "sadakatli hisseler" in Tasarının 661a maddesinde yer almasını kararlaştırmıştı ${ }^{75}$. 2020 yılı ilkbahar yasama döneminde ise Ständerat, baştan beri benimsediği karşı görüşünde israr etti ${ }^{76}$ ve böylece sadakatli hisselere ilişkin düzenlemeler 2020 tarihli E-OR'dan (Borçlar Hukuku Tasarısı) çıkarıldı. Tasarı, 19.6.2020'de parlamentoda kabul edilerek yasalaştı ${ }^{77}$. Ancak öğretide, konuya ilişkin tartışmaların sona ermediği ve öyle veya böyle, sadakatli hisseler sorununun İsviçre siyaseti ve hukukunu meşgul etmeye devam edeceği belirtilmektedir ${ }^{78}$.

Sadakatli hisselerle ilgili Tasarıda yer alan düzenlemeler esas itibariyle şöyleydi: Esas sözleşmede, en az iki yıl pay defterine oy hakkına sahip olarak kaydedilmiş olan hisselerin sahiplerine \%20'ye kadar daha fazla kâr payı verilebileceği öngörülebilir. Böyle bir hükmün esas sözleşmeye konulabilmesi için, IsvBK m. 704/1 uyarınca temsil edilen oyların en az üçte ikisinin ve oy hakkı bulunan esas sermayenin tamamının salt çoğunluğunun bir arada bulunan bir genel kurul kararını gerektirir ${ }^{79}$.

Ayrıca esas sözleşmede, pay defterine en az iki yıl süreyle kaydedilmiş olan hisse sahiplerinin, olağan sermaye artırımı çerçevesinde ihraç edilen yeni paylara ilişkin daha yüksek oranda rüçhan hakkına sahip olabileceği öngörülebilir ${ }^{80}$. Bunun için mevcut paysahiplerinin pay sermayesine katılma kapmasında sahip oldukları rüçhan hakkının genel kurul kararıyla kaldırılması gerekir ${ }^{81}$. Mevcut rüçhan haklarının sınırlandırılması, kaldırılması veya yeni rüçhan hakkının tanınması, İsvBK m. 704/1'de öngörülen nitelikli bir genel kurul kararıyla gerçekleşir. $\mathrm{Bu}$, olağan sermaye artırımına yapılan atıf nedeniyle, şartlı sermaye artırımında opsiyon hakkı sahiplerinin yeni pay alma hakkının kullanılmasında da uygulanabilir ${ }^{82}$.

75 AB 2019 N 2385 ff. Burckhardt, Loyalitätsaktien, s.378.

76 Burckhardt, Loyalitätsaktien, s.378. AB 2020.

77 Eingefügt durch Ziff. I des BG vom 19. Juni 2020 (Aktienrecht), in Kraft seit 1. Jan. 2021 (AS 2020 4005; BBl 2017 399). Ancak, yürürlük tarihi üç kısıma ayrıldı; örneğin, işletme konusu madencilik, ham petrol, doğal gaz gibi işlerle ilgili olan hammadde şirketlerinde şeffaflı̆̆a ilişkin İsvBK m. 964a-964f ile halka açık şirketlerin yönetim kurullarında her cinsiyetin \%30 ve icracı yönetici organlarında \%20 oranında temsiline ilişkin İsvBK m. 734a-734e hükümleri bağlayıcı olmamak üzere 1.1.2021‘de; aynı maddelerin bağlayıcı şekilde yürürlüğe girmesi ise 1.1.2025'de, diğer bazı hükümler ise aynı şekilde 1.1.2025 tarihinden itibaren yürürlüğe gireceği kararlaştırılmıştır.

78 Burckhardt, Loyalitätsaktien, s.378.

79 E-OR 2019. E-OR 2019, Art. 704 Abs. 1 Ziff. 8 bis

80 E-OR 2019, Art. 652b ${ }^{\text {bis }}$. Tüm paysahiplerine veya pay iktisap edenlere karşı esas sözleşme temelinde şeffaflık önemlidir.

81 Sadakatli hissedarların yeni çıkarılan esas sermaye paylarına ilişkin rüçhan hakkı \%20'ye kadar olabilir. E-OR 2019Art. $652 b^{\text {bis }}$ Abs.

82 Art. 652b ${ }^{\text {bis }}$ Art. 653c Abs. 1 hükmü bağlantısıyla, in fine E-OR 2019. Burckhardt, Loyalitätsaktien, s.379, dn. 67. 
Son olarak, sermaye artırımında pay defterine en az iki yıl süreyle kaydedilmiş yeni çıkarılan payların sahiplerine veya şartlı sermaye artırımında çıkarılan opsiyonlu borç senet sahiplerinin alım hakkını kullanması durumunda, \%20'ye kadar daha düşük bir ihraç primi ödeme yapma hakkı tanınabileceği öngörülmekteydi ${ }^{83}$.

Önemli bir husus, İsviçre Ulusal Meclisi’nde kabul edilen düzenlemede, uzun vadeli hissedar katılımları sadakatli temettü, rüçhan hakkı ve önerilmeye muhatap olma haklarıyla teşvik etmekte, buna karşın Fransız hukukunda olduğu gibi, daha fazla oy hakkı bahşeden sadakatli oy hakkı verilmemektedir ${ }^{84}$.

\section{YÖNETIM KURULUNDA KADIN KOTASI UYGULAMASI}

\section{A. Türk Hukukunda}

Türk Ticaret Kanununda anonim şirketlerin yönetim kurullarında "zorunlu" kadın kotası yer almamaktadır. Buna karşın, SPKr 2012 yılında yayımladığı Kurumsal Yönetim İlkeleri Tebliğinde, borsaya kote anonim şirketlerin yönetim kurullarında en az bir kadın üye bulundurma ilkesine yer verdi. 2014'de yayımlanmış olan (II-17.1) sayılı Kurumsal Yönetim İlkeleri Tebliğin EK-1 m. 4.3.9’a göre:

“Şirket, yönetim kurulunda kadın üye oranı için \% 25'ten az olmamak kaydıyla bir hedef oran ve hedef zaman belirler ve bu hedeflere ulaşmak için politika oluşturur. Yönetim kurulu bu hedeflere ulaşma hususunda sağlanan ilerlemeyi yıllık olarak değerlendirir”.

Kadın kotasına ilişkin bu ilke zorunlu olmayıp tavsiye niteliğindedir ${ }^{85}$.

\section{B. İsviçre Hukukunda}

İsviçre hukukunda yönetim kurulunda "cinsiyet eşitliği" ilkesinin uygulanması birçok Avrupa ülkesinde yasal düzenlemelerle hayata geçmeye başlamıştır. İsviçre "Anonim Şirketler Hukuku Büyük Revizyonu” kapsamında yönetim kurulunda kadın kotası (Frauenquote) üzerinde 10 yıla yakın devam etmekte olan tartışmaların henüz tam olarak sonuçlandığını söylemek pek de mümkün değildir. Cinsiyet eşitliği, 2014 tarihli Anonim Şirketler Revizyonuna ilişkin olarak en son 2020 tarihli Tasarıda, halka açı şirketlerin yönetim kurullarında her cinsiyetin \%30; icra kademesinde ise $\% 20$ 'şer oranda temsil edilmesi hükümleri (Art.734f) 19.6.2020'de yasalaşmıştır ${ }^{86}$. Ancak, bu hükümler bağlayıcı değil, sadece tavsiye niteliğinde olup, bağlayıcı şekilde uygulanması ise \%30’luk

83 Art. 652b Abs. 5 i.V.m. Art. 653c Abs. 1 in fine E-OR 2019. Burckhardt, Loyalitätsaktien, s. 379, dn. 68.

84 Burckhardt, Loyalitätsaktien, $s .379$

85 Bu konuda ayrıntılı bir araştırma için bkz. K. Şahin/B. Eser/T. Kaplan/G. Özdündar, Yönetim Kurullarında Kadın Yönetici Temsili: Türkiye’de Yönetim Kurulları Yapısının Cinsiyet Bağlamında İncelenmesi, Uluslararası Yönetim İktisat ve İşletme Dergisi, Cilt 14, Sayı 4, 2018, s. 1147 vd.

86 Eingefügt durch Ziff. I des BG vom 19. Juni 2020 (Aktienrecht), in Kraft seit 1. Jan. 2021 (AS 2020 4005; BBl 2017 399). 
kısım beş yıl, \%20'lik kısmının ise 10 yıl sonra yürürlüğe gireceği kararlaştırılmıştır. Dolayısıyla, söz konusu cinsiyetlerin temsili hükümlerine uyulmamanın bir yaptırımı yoktur ${ }^{87}$. Öte yandan, Anonim şirketlere ilişkin revizyon çalışmalarında yararlanılmak üzere İsviçre Adalet Bakanlığı, "İsviçre Mukayeseli Hukuk Araştırmaları Enstitüsü” nü Avrupa ülkelerinde anonim şirketlerin yönetim ve gözetim kurullarındaki "kadın kotası" hakkında bir rapor hazırlamakla görevlendirdi. Enstitünün 9 Ocak 2017 tarihli raporuna göre, Belçika, Fransa, Almanya, İtalya, Hollanda, Norveç ve Avusturya’da kanunlarında \%20 ile \%50 arasında değişen zorunlu kadın kotası öngörülmektedir ${ }^{88}$. Kadın kotası uygulaması genel olarak borsaya kote büyük anonim şirketlerin monist veya dualist yönetim sistemlerine göre, yönetim ve gözetim kurulları veya icra organları için öngörülmekte ve Norveç, Finlandiya, İtalya, Fransa, Belçika gibi ülkelerde kamuya ait veya kamu otoritesi kontrolündeki şirketlerde de kadın kotası düzenlemeleri yer almaktadır ${ }^{89}$.

Yukarıda belirtildiği üzere, 2019 tarihli İsvBK’daki anonim şirketlere ilişkin Tasarı, 19.6.2020'de Ulusal Mecliste kabul edilerek kanunlaşmışıı ${ }^{90}$. Yeni düzenlemede yönetim kurulunda cinsiyet kotasına yer verilmiştir. Nitekim İsvBK m. 734f'ye göre, yönetim kurulunda her cinsiyet en az \%30 oranında temsil edilmediği takdirde, 727. maddenin 1. fikrası N. 2'de yer alan eşikleri aşan şirketler;

1. Cinsiyetlerin öngörüldüğü gibi temsil edilmediğinin sebeplerini,

2. Daha az güçlü temsil edilenleri teşvik edecek önlemleri, ücret raporunda (Vergütungsbericht) açıllamaları gerekmektedir.

Yeni İsvBK m.734f hükmünde, anonim şirket yönetim kurullarındaki cinsiyet kotasına ilişkin İsvBK m. 727/1, N. 2'de iki eşik öngörülmektedir: Birincisi şrirketin borsaya kote olması ve merkezlerinin İsviçre'de bulunması; ikinci eşik ise ekonomik nitelikte olup, 20 milyon CHF toplam bilanço tutarı 40 milyon CHF satış geliri ile 250 tam zamanlı çalışanın, art arda iki hesap döneminde aşılması gerekmektedir. Öğretide, öncelikle Tasarının $734 \mathrm{f}$ maddesinde öngörülen cinsiyet politikasıyla ilgili hükmün atipik bir "uygula ya da açıkla" (Comply or explain) normu olduğu ve bu şekildeki bir normun da uygulama etkisinin olmaması nedeniyle, şrketlerin gerçekte bu kriterleri karşılayıp karşılamamakta tamamen serbest olacağı belirtilmektedir. Ayrıca, şirketlerin, İsvBK m. 727/1. N. 2'deki 20 milyon CHF toplam bilanço tutarı ve 40 milyon CHF satış gelirinin cinsiyet kotası ve bunun ücret raporunda açıklanmasıyla ne ilgisinin olduğunun da anlaşılmasının güç olduğu belirtilerek, söz konusu düzenlemeye haklı eleştiriler yöneltilmektedir ${ }^{91}$.

87 Peter Forstmoser/ Marcel Küchler, Schweizer Aktienrecht 2020. Zum Stand der schweizerischen Aktienrechtsreform, Expert Fokus/2016 1-2, s. 86 vd (94) (https://www.forstmoser.ch/wp-content/publications/articles/2016-2020.pdf. Erişim. 23.3.2021)

88 Gutachten zu Geschlechterquoten im Aktienrecht von Schweizerisches Institut für Rechtsvergleichung, Abstract, s. 1, ayrıntılı bilgi için s. 8-18.

89 Gutachten zu Geschlechterquoten im Aktienrecht von Schweizerisches Institut für Rechtsvergleichung, s.1 ve s. 8-17.

90 Bkz. Forstmoser/Küchler, Schweizerisches Gesellschaftsrecht Mit neuem Firmen - und künftigem Handelsregisterrecht und unter Einbezug der Aktienrechtsreform Update zur 12. Auflage 2018 - Stand Ende September 2020, Vorwort. (https://www.forstmoser.ch/wp-content/publications/misc/updategesr12.pdf. Erişim. 20.3.2021). YK’da her cinsiyetin \%30 oranında temsil edilmesi hükmü beş yıl, kadın kotası ise 10 yıl sonra tam olarak yürürlüğe girecektir.

91 Matthias P. A Müller/ Lucas Forrer, Geschlechterrichtwerte im Entwurf für ein neues Aktienrecht, AJP 2019, s. 1015. 


\section{Alman Hukukunda}

Avrupa Parlamentosunun "cinsiyet kotas1" (Geschlechterquoten) ile ilgili (2013/34/EU ve 2014/95/ EU) iki Direktifi üzerine, 24 Nisan 2015’te Alman Anonim Şirketler Kanunu'nda (AktG) yönetici kurulunun (Vorstand) düzenlendiği AktG $\$ 76$ hükmüne 4. fikra eklendi ve kadın ve erkeklerin şirketlerin yönetici kademesinde \%30'ar oranda eşit temsil edilmesi kabul edildi. 1.1.2016'dan itibaren yürürlüğe girmiş olan $A k t G ~ \$ 76$ hükmüne 4. fikra hükmüne göre;

"Borsaya kote şirketler veya Yönetime Katılma Kanunlarına tabi olan şirketlerde yönetici kurul, altındaki her iki yönetim kademesinde yer alan kadın katılımların oranı için hedef oranlarını belirler. Belirlenen hedef oranlar \%30'un altında ise, bu oranlar her halde ulaşılan yüzdenin altına düşmez. Aynı zamanda hedef değerlere ulaşabilmek için zaman belirlenir. Ancak bu süre hiçbir şekilde beş yildan uzun olmaz".

Aynı şekilde, gözetim kurulunun (Aufsichtsrat) düzenlendiği AktG $\$$ 96/2 de de özetle, çeşitli Yönetim Katılma Kanunlarına tabi borsaya kote şirketlerin ve çalışan temsilcilerinin yönetimde eşit söz hakkı olduğu gözetim kurulu, \%30 kadınlardan ve \%30 erkeklerden eşit olarak oluşur. Aynı kural, Avrupa Anonim Şirketi (SE) için de geçerlidir. Bu kotalara aykırı yapılan gözetim kurulu üyelikleri seçimi geçersizdir. Öngörülen kotadan az temsil edilen (kadın ve erkeklere ilişkin) cinsiyet koltukları boş kalır. Bu durum öğretide, "boş koltuk prensibi” (Prinzip des "leeren Stuhls”) olarak tanımlanmaktadır ${ }^{92}$.

Hemen belirtelim, AktG’de öngörülen kadın kotası düzenlemeleri zorunlu değil, tavsiye niteliğindedir. Alman Federal Hükümeti bu kuralların zorunlu olarak uygulanmasına ilişkin koalisyon ortağı ile uzlaşma sağlandığını belirtmiştir. Buna göre, borsaya kote şirketler ile kamu kurumu işletmelerin gözetim ve yönetim organlarında üçten fazla üyenin olduğu gözetim kurullarında en az birinin kadın olmasına ilişkin Hükümet Tasarısı, “Entwurf eines Gesetzes zur Ergänzung und Änderung der Regelungen für die gleichberechtigte Teilhabe von Frauen an Führungspositionen in der Privatwirtschaft und im öffentlichen Dienst" 6.1.2021'de parlamentoya sunulmuş ve böylece yasalaşma süreci başlamış $\mathrm{oldu}^{93}$. Buna göre, özel hukuka tabi borsaya kote şirketlerin gözetim organlarında ve aynı zamanda çalışan temsilcilerinin yönetimde eşit söz ve oy hakkı olduğu işletmelerde sabit (fiks) bir kadın kotası belirlenmiş olup, ayrıca borsaya kote ve çeşitli yönetime katılma kanunlarına ${ }^{94}$ tabi şirketlerin her iki gözetim ve yönetim organları için esnek kota uygulanacağı öngörülmüştür. Nihai olarak kadınların ve erkeklerin şirketlerin tepe yönetimine eşit katılımlarının 31.12.2025 tarihine kadar gerçekleştirilmesi kabul edilmiştir 95 .

92 Hartmut Oetker, in: Erfurter Kommentar zum Arbeitsrecht, 17. Auflage, München 2017, §96 AktG Rn. 7 (Gutachten zu Geschlechterquoten im Aktienrecht, s. 9'dan naklen)

93 Alman anonim şirketler hukukunda gözetim kurulu (Aufsichtsrat) hem paysahiplerin temsilcilerinden (Anteilseignervertreter) hem de çalışanların temsilcilerinden (Arbeitnehmervertreter) oluşmaktadır (AktG $\$ 100 / 3,101 \mathrm{vd}$.)

94 Alman hukukunda 5 adet Yönetime Katılma Kanunu (Mitbestimmungsgesetz) bulunmaktadır Bunlar: (1). MontanMitbestimmungsgesetzvon 1951,(2). Betriebsverfassungsgesetzvom 11.Oktober 1952,(3). Betriebsverfassungsgesetz vom 15. Januar 1972, (4). Mitbestimmungsgesetz vom 4. Mai 1976 ve (5). Drittelbeteiligungsgesetz vom 18. Mai 2004. 


\section{V. ÇOK ULUSLU ŞIRKETLERIN MERKEZ YÖNETIM ORGANININ BAĞLI VEYA YAVRU ŞIRKETLERIN INSAN HAKLARI ÇEVRE STANDARTLARININ IHLALLERINDEN HUKUKI SORUMLULUĞUNUN OLUP OLMADIĞI SORUNU}

\section{A. Türk hukukunda}

Türk hukukunda küresel faaliyette bulunan şirketlerin ana şirketinin yavru veya bağlı şirketlerinin yurt dışı faaliyetlerinde insan hakları ve çevrenin korunmasını ihlal eden iş ve eylemleriyle ilgili merkezi yönetim organının özen yükümünü düzenleyen genel ve özel nitelikte bir hüküm yer almamaktadır.

Ayrıca, uzun vadeli ve sürdürülebilir şirket politikası ve uluslararası genel kabul gören insan hakları ve çevre standartlarının korunmasıyla ilgili mevcut Türk ticaret mevzuatında da özel bir hüküm olmamakla birlikte, yönetim kurulunun Compliance (uyum) sorumluluğu olarak anılan TTK m. 375/1-e bendi hükmünün, dolaylı olarak uygulanabileceği düşünülebilir. Bu maddede, yönetim kurulunun devredilemez ve vazgeçilemez görev ve yetkileri arasında; yönetimle görevli kişilerin, özellikle kanunlara, esas sözleşmeye, iç yönergelere ve yönetim kurulunun yazılı talimatlarına uygun hareket edip etmediklerinin üst gözetimi” yer almaktadır ${ }^{96}$. Önemle belirtelim ki, uyulması gereken düzenlemeler veya talimatlar, sadece milli hukukla sınırlı değil, aksine özellikle küresel düzeyde faaliyette bulunan büyük şirketlerin, faaliyette bulundukları ülkenin ve ayrıca uluslararası geçerliliğe sahip anlaşmalar ${ }^{97}$ ve insan hakları ve çevrenin korunması gibi genel kabul gören standartlar da bu kapsama dâhildir olup, bunlara uygun hareket etmelerini kapsar. Şirketin faaliyeti nedeniyle zarara uğrayanların açacağı tazminat davaları doğrudan şirketin tüzel kişiliğine karşı açılır. Çünkü yönetim kurulu üyeleri ve yönetimle görevli kişilerin kanuna, esas sözleşmeye ve diğer ilgili düzenlemelere aykırı işlem ve eylemleri haksız fiil teşkil eder ve TTK m. 371/5, OR Art. 722 uyarınca, temsile veya yönetimle görevli olanların, görevlerini yaptıkları sırada işledikleri haksız fiillerden de şirket sorumludur. Ancak şirket, daha sonra kanundan ve esas sözleşmeden doğan yükümlülüklerini kusurlarıyla ihlal ettikleri nedeniyle yönetim kurulu üyeleri ve yöneticilere rücu edebilir (TTK m. 553/1, 557/1, 369/1; OR Art. 754/1, 2; 757; 717/1).

Ancak, Türk hukukunda şirketler topluluğuyla ilgili olarak TTK m. 203'de, "bir ticaret şirketi bir sermaye şirketinin paylarının ve oy haklarının doğrudan veya dolayl olarak yüzde yüzüne sahipse, hâkim şirketin yönetim kurulu, topluluğun belirlenmiş ve somut politikalarının gereği olmak şartıyla... bağl şirketin yönlendirmesine ve yönetimine ilişkin talimat verebileceği ve bağh şirketin organlarının da talimata uymak zorunda" olduğuna göre, ana şirket, şirket politikası hakkında - nerede faaliyette

96 Bu konuda bkz. H. Pulaşlı, Compliance Kavramı ve Yönetim Organının Compliance Sorumluluğu, Batider, C.XXXV, Sa.2, s. 27-59 (34). Bu hükümde, öncelikle yönetim kurulunun temsil yetkisinin bir veya birkaç YK üyesine ya da üçüncü bir kişiye devredilmesi halinde yönetim kurulunun, cura in custodiendo (denetimde özen yükümü) çerçevesinde bu kişileri denetleme yükümü söz konusudur. İkinci olarak üst gözetim, bir yandan TTK’da yasalara uygun hareket etmeye ilişkin normatif düzenlemeleri (halka açık şirketlerde içerden öğrenilen cezai hükümlerine ilişkin yükümlülükler), diğer yandan da esas sözleşme, iç yönerge ve talimatlara uyulması hususunda gözetimi kapsamaktadır. Bkz. Watter/Roth Pellanda, Basler Kommentar, 4. Aufl. Basel 2012, Art. 716a, N. 24.

97 Kırca/Şehirali Çelik/Manavgat, Anonim Şirketler Hukuku, C. I, Ankara 2013, s. 562, Pulaşlı, Anonim Şirketlerde Temsil Şekli, Özel Temsil Halleri ve Temsil Yetkisinin Murahhaslara Devri, Batider, C.XXXV, Sa .2, s. 5-39 (32-33). 
bulunursa bulunsun - yavru şirket yönetimine talimat vermek hakkını haizdir. Dolayısıyla, uluslararası genel kabul gören insan hakları ve çevre standartlarına mutlak olarak uygun hareket edilmesi talimatını vermesi gerekir. Bunun ihmal edilmesi halinde sorumlu olacağı söylenebilir ${ }^{98}$.

\section{B. İsviçre Öğretisinde}

İsviçre’de, Alman ve Türk hukukundaki gibi, konzern hukukunun pozitif olarak düzenlendiği açı bir yasal düzenleme mevcut olmayıp, sadece Borçlar Kanununda, 1993'de yürürlüğe giren konzern finansal tablolara (Konzernrechnung) ilişkin m. 963, 963a ve 963b hükümleri yer almaktadır. Ayrıca, 1.1.2021'de kanunlaşıp, yürürlüğe giren 2019 tarihli Anonim Şirketler Revizyonuna ilişkin Tasarısında da bir değişiklik öngörülmemiş olduğundan, yönetim kurulu üyelerinin özen yükümü ve buna ilişkin hukuki sorumluluğu İsvBK m.716a hükmüne göre tespit edilmektedir.

Öğretide bu konuda iki önemli görüş yer almaktadır. Bunlardan ilki Forstmoser tarafından temsil edilmektedir. Yazar, küresel faaliyette bulunan büyük şirketlerin kamuya yaptığı ve özünde PR (halkla ilişkiler) ve pazarlama amaçlı olan bu açıklamaların aynı değerde yıllık finansal raporlarda da yer aldığını ve bu raporların - finansal raporlamaya benzer şekilde- denetçiler veya bağımsız kurumlar tarafından incelenmesinin ciddi olarak düşünülebileceğini ${ }^{99}$ ve bu açılamaların kavramsal olarak, bir yandan yalnızca paysahiplerinin çıkarlarına odaklandığını, diğer yandan da kişisel ve ortak çıkarların dengeli bir şekilde dikkate alınarak iki taraflı bir çarpışmanın söz konusu olduğunu belirtmekte ve devamla, gerçekte pratik uygulama açısından sadece çok istisnai bir farkın olduğunu ve hisse senedi yatırımcılarının (Shareholder) menfaatleri ile diğer menfaat sahiplerinin (Stakeholder) çıkarları arasında da zor durumlarda bir çatlağın ortaya çıkabileceğini ifade etmekte ve kural olarak, değer dağıtımına değil, değer artırmaya odağında- iki hedefin birlikte el ele gittiği sürece paydaşlar için değer yaratılabilmenin başarılı olabileceğini belirtmektedir. ${ }^{100}$ Yazar, konuyu spesifik olarak incelediği "Schutz der Menschenrechte - ein Pflicht für Mültinationale Unternehmer?" (İnsan Hakları - Çok Uluslu Şirketler İçin Bir Yükümlülük müdür?) başlıklı makalesinde ise, ana şirket yavru şirket arasındaki (hukuki sorumluluk) ayrımı ilkesi bakımından sorunun İsviçre hukuku açısından açık olduğunu, zira ana şirket ve yavru şirketin ekonomik açıdan bir bütünlük oluştursalar da, hukuken bağımsız kurumlar olduğunu; bir yavru şirketin -ister sözleşme isterse haksız fiil - davranışlarından olsun, münhasıran tüzel kişi olarak kendisi ve -geçerli ulusal hukuka göre - organ üyelerinin sorumlu olduğunu ve anonim şirketler hukukunda ana şirketler için geçerli olan prensibe göre, paysahipleri ve - ana şirket veya yavru şirketin tek veya hâkim paysahibi de dâhil - ana şirketin, yavru şirketlerin yükümlülüklerinden kişisel olarak sorumlu olmadığını; Nestlé şirketinin Kolombiyalı yavru şirketinin ve kendi çevresinde - ve eski çalışanları

98 Ayrıntılı açıklamalar için bkz. Pulaşlı, Compliance, Batider, Batider, C.XXXV, Sa.2, s. 51 vd.

99 Forstmoser, Corporate Social Responsibility, s. 159. Yazar, Haziran 2014 tarihli Global Raporlama İnisiyatifinin (Global Reporting Initiative "GRI) standartlaştırılan ve karşılaştııılan bir raporunda, İsviçre şirketlerinin \% 90’ının sürdürülebilirlik raporlarında (Nachhaltigkeitsberichten) GRI standartlarının dikkate aldığını belirtmektedir (s. 159, dn. $8)$.

100 Forstmoser, Schutz der Menschenrechte -eine Pflicht für multinationale Unternehmen? İn: Liber amicorum für Andreas Donatsch Im Einsatz für Wissenschaft, Lehre und Praxis, Bern 2012, s. 704 ff. s. 719. 
da dâhil olmak üzere - koruma ve sağlama yükümünü göz ardı etmesi halinde, bunun hukuki sonuçlarından doğrudan yavru şirketin ve gerektiğinde onun organının sorumlu olduğunu; bunun, ekonomik bütünlüğe bağlı olarak konzern konseptine karşıllk gelmekle birlikte, (şekli) hukuki olarak tüzel kişiliğe ve aynı zamanda şubeleri ve çok uluslu şirketin organizasyonu ile bağımsız yavru şirketlerin bulunduğu bir organizasyonda sermaye karşıtlığına da uygun düşeceğini ileri sürmektedir ${ }^{101}$.

Böckli/Bühler ise, "sınır tanımayan hukuk" organizasyonu çerçevesinde İsviçreli kadın dernekleri, sendikalar, kilise temsilcileri ve bazı paysahipleri dernekleri gibi sivil toplum kuruluşlarından oluşan kısaca "konzern sorumluluk inisiyatifi" («Konzernverantwortungsinitiative») olarak anılan organizasyonun, İsviçre Anayasasının 101a maddesinin 2. fikra olarak eklenmesini önerdiği düzenlemenin, "İsviçre şirketlerinin dünyanın her hangi bir yerinde gerçekleșen ve insan haklarına ve çevreye aykırılikla bağlantılı olabilecek her olayı İsiçre de dava edilmesine imkân tanınması" şeklinde olduğunu, ${ }^{102}$ ve bu durumda tazminat davalarının, artık zararın sadece meydana geldiği ülkede değil, başka ülkedeki bir mahkemede açılabileceği belirtmektedir. Ancak, merkezi İsviçre bulunan bir küresel faaliyette bulunan bir şirketin başka bir ülkede faaliyette bulunan yavru/ bağlı şirketinin insan hakları ve çevre standartlarının ihlali nedeniyle meydana gelen zararlar için İsviçre'deki bir mahkemede dava açabilmesi halinde, aşılması zor dava prosedürü ve pratik engellerle karşılaşabileceği, ayrıca sınır ötesi süreçte de kanıt toplamanın zorluğu bir yana, bir İsviçre mahkemesinin başka bir ülkede resmi işlemler yapması yasaklandığından, herhangi bir kanıt toplama eylemine de izin verilmeyeceğini yerinde olarak ifade etmektedirler. Aynı şekilde, bir İsviçre mahkemesinin başka bir ülkenin kamu kurumlarına emredici nitelikte direktif vermesi de mümkün olmadığını, çünkü o ülkenin egemenlik hakkıyla bağdaşmayacağını ${ }^{103}$ ve konzern sorumluluk inisiyatifinin İsviçre’de yürüttügü "sınır tanımayan hukuk" (Recht ohne Grenzen) kampanyasının, hem günümüzün sıkı dokunmuş uluslararası standartlarının büyük önemini hem de İsviçre’de yürürlükte olan konzernlerin tepe yönetiminin mevcut sorumluluğuna ilişkin hukuki kuralların uygulanmasını hafife aldığını, ayrıca "sınır tanımayan hukuk" kampanyasının çok ileri düzeyde ek yükümlülükler getirdiğini ve bunun da İsviçreli konzernlerin ana şirketlerini yeni bir tür hukuki sorumluluk sorunları ve hukuk güvenliği riskine maruz bırakacağını; her şeyden önce ana şirketin tüm bağl şirketleri için genel doğrudan bir sorumluluk getirilmesi ve insan hakları ve çevre standartları alanına ilişkin kural ihlalleriyle ilgili sorumluluğunun, yabancı grup şirketlerine hizmet veren üçüncü şirketler vasıtasıyla genişletilmesinin son derece ileri gittiğini, sonuçta, esasen sorunun odak noktasının, zayıf devletlerin yurt dışında uygulayamadıklarının genel garantörü olarak içerdeki

101 Forstmoser, Corporate Social Responsibility, s. 160.

102 Federal Meclis'in (Nationalrat), 1.4.2015 tarihli bağlayıcı olmayan bir bildirim ile "sınır tanımayan hukuk" kampanyasına saygı duyulduğu yazılı açıklaması, kısa adı "Konzern sorumluluk inisiyatifi” ("Konzernverantwortungsinitiative») olan halk inisiyatifi tarafından yetersiz bulundu ve İsviçre Federal Anayasasına 101a madde olarak eklenmesi talebiyle 120.000 resmi onaylı imza toplayarak 10 Ekim 2016'da parlamentoya başvuruda bulundu. Sürecin bir halk oylamasiyla sonuçlanacağı anlaşılmaktadır. Bkz. Bühler, Zürcher Kommentar, 3.Aufl. 2018, Art. 717, N. 16.

103 Peter Böckli/Cristian B. Bühler, Konzernverantwortung ohne Grenzen, Entwicklungen im Gesellschaftsrecht XII, Bern 2017, s. $146 \mathrm{vd}$ 
İsviçre şirketlerinin bunu tazmin etmelerini istendiğini ve bunun da kuşkusuz, İsviçre için ciddi bir lokasyon dezavantajına sebep olacağını ileri sürmektedirler ${ }^{104}$.

\section{KAYNAKÇA}

Akbulut, Nazire İsviçre'li Kadınların 170 Yıllık Mücadelesi. (https://www.evrensel.net/haber/425382/isvicrelikadinlarin-170-yillik-mucadelesi).

Ansay, Tuğrul, Anonim Şirketler Hukuku, 6. Bası Ankara 1982.

Belinfanti, Tamara C. Shareholder Cultivation And New Governance, Delaware Journal Of Corporate Law [Vol. 38), 2014, s. 790 ff.

Biedermann, Dominique/Daenıker Danıel, Pro \& Contra: Soll die Generalversammlung Managersaläre genehmigen? GesKR 2008, $142 \mathrm{ff}$.

Böckli, Peter/ Bühler, Cristian B. Konzernverantwortung ohne Grenzen, Entwicklungen im Gesellschaftsrecht XII, Bern 2017, s. 146 vd.

Burckhardt, Christoph, Loyalitätsaktien im Rahmen der Aktienrechtsrevision, Das Aktienrecht im Wandel Zum 50. Geburtstag von Hans-Ueli Vogt, Dike Verlag AG, Zürich/St. Gallen 2020, s. 367-386.

Coşkun Arslan, Mihriban/Kısacık Harun, The corporate Sustainability Solution: Triple Bottom Line, Muhasebe ve Finansman Dergisi Temmuz 2017 Özel Sayı, s. 18-34.

von der Crone, Hans Caspar/ Mohasseb Keivan, Stand der Aktienrechtsrevision Zehn Kernpunkte der ständerätlichen Debatte, AJP/PJA 8/2019, s. 781-794

Forrer, Lucas, Geschlechterrichtwerte im Entwurf für ein neues Aktienrecht. Eine Auslegeordnung, AJP 2019, S. 1015-1031.

Forrer, Lucas, / Müller, Matthias P. A. Geschlechterrichtwerte im Entwurf für ein neues Aktienrecht. Eine Auslegeordnung, AJP 2019, S. 1015-1031

Forstmoser, Peter, Gewinnmaximierung oder soziale Verantwortung? Zum Auftragbörsennotierter Unternehmen (https://www.forstmoser.ch/wp-content/publications/articles/2005-gewinnmaximierung.pdf).

Forstmoser.P/Meier-Hayoz. A./Nobel, P. Aktienrecht, Bern 1996.

Forstmoser, Peter, Profit - Das Mass aller Dinge? Zur Aufgabe börsenkotierter Unternehmen, in: Festgabe zum schweizerischen Juristentag, Zürich 2006, s. $55 \mathrm{ff}$.

Forstmoser, Peter, Gewinnmaximierung oder soziale Verantwortung?' Zum Auftrag börsennotierter Unternehmen. In Summa: Dieter Simon zum 70. Geburtstag 2015, s. 207 ff.

Forstmoser, Peter, Schutz der Menschenrechte -eine Pflicht für multinationale Unternehmen? İn: Liber amicorum für Andreas Donatsch Im Einsatz für Wissenschaft, Lehre und Praxis, Bern 2012, s. 704 ff.

Forstmoser, Peter, Corporate Social Responsibility, eine (neue) Rechtspflicht für Publikumsgesellschaften? in: Robert Waldburger et al. (Hrsg.), Law \& Economics, Festschrift für Peter Nobel zum 70. Geburtstag, Bern 2015, 157 ff.

Forstmoser, Peter/Küchler, Marcel, Schweizer Aktienrecht 2020. Zum Stand der schweizerischen Aktienrechtsreform, Expert Fokus/2016 1-2, s. 86 vd (94). (https://www.forstmoser.ch/wp-content/ publications/articles/2016-2020.pdf).

Forstmoser/Küchler, Schweizerisches Gesellschaftsrecht Mit neuem Firmen - und künftigem Handelsregisterrecht und unter Einbezug der Aktienrechtsreform Update zur 12. Auflage 2018

104 Böckli/Bühler, Konzernverantwortung, s. 165-166. Ayrıntılı bilgi için bkz. Pulaşl1, Kurumsal Sosyal Sorumluluk, s. 31-33. 
- Stand Ende September 2020, Vorwort. (https://www.forstmoser.ch/wp-content/publications/misc/ updategesr12.pdf).

Danaeker, Daniel, Loyalitätsaktien - Postulat oder Rechtswirklichkeit? Sonder - druck aus Europa Institut Zürich Band 160 Mergers \& Acquisitions XVII Herausgeber: Rudolf Tschäni, Schultess Zürich 2015, s. 139-170 (https://silo.tips/download/loyalittsaktien-postulat-oder-rechtswirklichkeit).

Gatley, Neill, Introducing creating shared value, (https://www.british-assessment.co.uk/insights/spotlightintroducing-concept-creating-shared-value/).

Guhl, Theo, Das schweizerische Obligationenrecht, 9. Auflage, Zürich 2000.

Kaçamak, Sibel, Nancy'nin (Kurumsal Sosyal Sorumluluk (çeviri), 2. basım, İstanbul 2008.

Kırca/Şehirali Çelik/Manavgat, Anonim Şirketler Hukuku C. 1, Ankara 2013.

Lambert, Claude, Das Gesellschaftsinteresse als Verhaltensmaxime des Verwaltungsrates der Aktiengesellschaft, Diss. Zürich 1992.

Meier-Hayoz.A./Forstmoser.P/Sethe R. Schweizerisches Gesellschaftsrecht - Mit neuem Firmen und künftigem Handelsregisterrecht und unter Einbezug der Aktienrechtsreform, 12. A. Bern 2018.

Oetker Hartmut, in: Erfurter Kommentar zum Arbeitsrecht, 17. Auflage, München 2017.

Porter Michael E. And R. Kramer Mark, Creating Shared Value, Harvard Business Review (January -February, 2011, 89 (1-2) 62-77).

Pulaşlı, Hasan, Şirketler Hukuku Şerhi, 3. baskı Ankara 2018.

Pulaşlı, Hasan, Compliance Kavramı ve Yönetim Organının Compliance Sorumluluğu, Batider 2019, C.XXXV, Sa. 2, s. 27 vd.

Pulaşl, Hasan, Anonim Şirketlerde Temsil Şekli, Özel Temsil Halleri ve Temsil Yetkisinin Murahhaslara Devri, Batider 2020, C.XXXV, Sa.2, s. 32-33.

Pulaşlı, Hasan, Kurumsal Sosyal Sorumluluk Bağlamında Uluslararası İnsan Hakları ve Çevre Standartlarının Çok Uluslu Şirketlerin Merkez Yönetim Organının Hukuki Sorumluluğuna Etkisi, Batider 2020, C. XXXVI, S.4, s. 5-37.

Solmaz Başak, İşletmelerin Değişen Konumuyla Gelişen Kurumsal Sosyal Sorumluluk Bilinci Ve Turkcell'in Desteklediği “Çağdaş Türkiye'nin Çağdaş Kızları” Projesinin Genel Bir Değerlendirmesi, Selçuk İletişim, DerPark, 2013-11-19, s. 116-125.

Storck Michael/Schneider Uwe H. Doppeltes Stimmrecht für langfristig investierte Aktionäre im französischen Recht - Ein Beitrag zur «Nachhaltigkeitsprämie», AG 2008, 700 ff.

Şahin K./ Eser B./Kaplan. T/Özdündar G, Yönetim Kurullarında Kadın Yönetici Temsili: Türkiye’de Yönetim Kurulları Yapısının Cinsiyet Bağlamında İncelenmesi, Uluslararası Yönetim İktisat ve İşletme Dergisi, Cilt 14, Say1 4, 2018, s. 1147 vd.

Şehirali Çelik F.H/ Kırca. İ/ Manavgat. Ç, Anonim Şirketler Hukuku, C.1. Ankara 2013.

Tokgöz Nuray Önce/Saime, Şirket Sürdürülebilirliği İçin Yeni Ölçümleme: Üçlï Performans, Afyon Kocatepe Üniversitesi, İ.İ.B.F. Dergisi, (2009), V. 1, pp. 249 - 27.

Walter Schluep, Schutz des Aktionärs auf neuen Wegen? SAG 1960/61, 137 ff.

Watter Rolf, Anchor Shareholders und Grossaktionäre: Ihr Einstieg, ihre vertragliche Einbindung und ihre Information, in: M\&A XII, Zürich 2010, 1 ff.

Wolfhart F. Bürgi, in: Kommentar zum Schweizerischen Zivilgesetzbuch, Das Obligationenrecht, 5. Teil: Die Aktiengesellschaft, b/1: Rechte und Pflichten der Aktionäre (Art. 660-697), Zürich 1957. 